\title{
実験計画法を用いた最適条件探索プログラムの開発
}

田辺 郁男 ${ }^{* 1}$, 高橋 宗一郎*2, 高橋 智*1

\section{Development of the program for searching the optimum condition using design of experiments}

\author{
Ikuo TANABE $^{* 1}$, Sohichiro TAKAHASHI ${ }^{* 2}$ and Satoshi TAKAHASHI ${ }^{* 1}$ \\ ${ }^{* 1}$ Nagaoka University of Technology, Dept. of Mechanical Engineering \\ 1603-1 Kamitomioka-machi, Nagaoka-shi, Niigata 940-2188, Japan \\ ${ }^{*}$ Nagaoka University of Technology. Master course, Dept. of Mechanical Engineering \\ 1603-1 Kamitomioka-machi, Nagaoka-shi, Niigata 940-2188, Japan
}

Received: 29 March 2018; Revised: 30 April 2018; Accepted: 30 May 2018

\begin{abstract}
The Design of Experiments (DOE) is a method that is widely used due to its effectiveness to select optimum conditions in the design stage of product development. On the other hand, a fast, low cost, labor saving and energy-saving innovative development is also required in industry. In this research, a program for quickly searching the optimum condition using design of experiments is developed and evaluated. Relationships between each parameter and the final property are firstly cleared for each formula by using the design of experiments. Then the optimum conditions for each parameter were decided by using these formulas in a program. The optimum final property with each optimum level value were calculated. In addition, the optimum condition for cooling system using alkaline water mist was investigated for evaluating this program in an experiment. It is concluded from the result that (1) the program using the design of experiments was useful for fast development process, (2) this program could quickly and accurately decide the optimum cooling condition for cooling system using alkaline water mist.
\end{abstract}

Keywords: Design of experiments, Optimum design, Program, Optimum condition

\section{1. 緒言}

実験計画法は, 制御因子の水準值の最適組合せを効率よく決定するために産業界でよく利用されている(森他, 2016), (西岡, 伊藤, 2004)。また, 品質工学（静特性）は, 実験計画法をベースに誤差因子の概念を組込み, 口 バスト性の高い設計手法として, 多くの研究が行われている(藤川, 1999)，(西岡, 伊藤, 2004), (清水他, 2016),

(神蔵他, 2006), (小村他, 2012), (水谷他, 2002), (結城, 甲斐, 2013), (井山他, 2009). しかし, これらの 研究の多くは, 効果的な事例研究として要因効果図を求め, それを用いて 2 段設計を行うに留まっている.

それに対して，新たな利用法として，著者ら（Tanabe et al., 2014）は品質工学（静特性）の 1 回目のトライアル の結果をもとに，2 回目のトライアルにおいてその制御因子の最適水準值を探索するプログラムを開発してい る.しかし，1(1)のプログラムは品質工学をベースにしているため, 誤差因子の数のトライアルが必要であり, 最適条件探索までには長時間を有することと, (2)探索途中で最終特性值と各制御因子の関数関係を求める際の力 ーブフィット作業において，探索精度を上げるためには作業者の熟練度が必要であった.

そこで本研究では, 実験計画法を使用して, 品質工学（静特性）の誤差因子数分だけ実験回数を減らし，つぎ に, 最終特性值と各制御因子の関数関係を求める際のカーブフィット作業の自動化を行ない, さらに, 最適最終 特性值を得るための制御因子の水準值の組合せを 1 回のトライアルのみで計算できるプログラムを開発した。最

No.18-00171 [DOI:10.1299/transjsme.18-00171], J-STAGE Advance Publication date : 7 June, 2018

*1 正員，長岡技術科学大学（广940-2188 新潟県長岡市上富岡 1603-1）

*2 長岡技術科学大学 大学院

E-mail of corresponding author: tanabe@mech.nagaokaut.ac.jp 
後に, 開発したプログラムを用いて, 強アルカリ水ミストを用いた強制冷却システムの最適稼動条件探索を行い, 開発した最適条件探索プログラムの有効性を評価した.

\section{2.使用する実験計画法の説明}

実験計画法は, 最小限の実験もしくは CAE 等の解析で, 想定している設計パラメータの全組合せの中から, 最 適な設計条件を推定する手法である．表 1 に示すように設計パラメータに相当するものを制御因子（A～D），そ のパラメータの種類や数值に相当するものを制御因子の水準 $\left(A_{1} \sim D_{3}\right)$, その制御因子の組合せで最終的に起こる 現象を数值化したものを最終特性值とそれぞれ呼ぶ. この最終特性值について，全ての制御因子の水準組合せを 検討することは, 実際の開発現場においてはコストと時間がかかるため困難である.そのため表 2 に示すように, 直交表を用いて条件の割り付けを行い，制御因子の水準組合せを決定する．つぎに，この直交表の組合せに従っ て実験もしくはCAEを行い，その結果から最終特性值 $P$ を把握する.

各制御因子 $\mathrm{A}, \mathrm{B}, \mathrm{C}, \mathrm{D}$ の最終特性值 $P$ への影響 $E$ は, 最終特性值 $P$ を使って式(1)で計算できる.

$$
\begin{aligned}
& E_{\mathrm{A} 1}=\left(P_{\mathrm{A} 1 . \mathrm{B} 1 . \mathrm{C} 1 . \mathrm{D} 1}+P_{\mathrm{A} 1 . \mathrm{B} 2 . \mathrm{C} 2 . \mathrm{D} 2}+P_{\mathrm{A} 1 . \mathrm{B} 3 . \mathrm{C} 3 . \mathrm{D} 3}\right) / 3 \\
& E_{\mathrm{A} 2}=\left(P_{\mathrm{A} 2 \cdot \mathrm{B} 1 . \mathrm{C} 2 \cdot \mathrm{D} 3}+P_{\mathrm{A} 2 \cdot \mathrm{B} 2 \cdot \mathrm{C} 3 \cdot \mathrm{D} 1}+P_{\mathrm{A} 2 \cdot \mathrm{B} 3 \cdot \mathrm{C} 1 \cdot \mathrm{D} 2}\right) / 3 \\
& E_{\mathrm{A} 3}=\left(P_{\mathrm{A} 3 \cdot \mathrm{B} 1 . \mathrm{C} 3 \cdot \mathrm{D} 2}+P_{\mathrm{A} 3 \cdot \mathrm{B} 2 \cdot \mathrm{C} 1 . \mathrm{D} 3}+P_{\mathrm{A} 3 \cdot \mathrm{B} 3 \cdot \mathrm{C} 2 \cdot \mathrm{D} 1}\right) / 3 \\
& E_{\mathrm{B} 1}=\left(P_{\mathrm{A} 1 \cdot \mathrm{B} 1 \cdot \mathrm{C} 1 \cdot \mathrm{D} 1}+P_{\mathrm{A} 2 \cdot \mathrm{B} 1 \cdot \mathrm{C} 2 \cdot \mathrm{D} 3}+P_{\mathrm{A} 3 \cdot \mathrm{B} 1 \cdot \mathrm{C} 3 \cdot \mathrm{D} 2}\right) / 3 \\
& E_{\mathrm{B} 2}=\left(P_{\mathrm{A} 1 \cdot \mathrm{B} 2 \cdot \mathrm{C} 2 \cdot \mathrm{D} 2}+P_{\mathrm{A} 2 \cdot \mathrm{B} 2 \cdot \mathrm{C} 3 \cdot \mathrm{D} 1}+P_{\mathrm{A} 3 \cdot \mathrm{B} 2 \cdot \mathrm{C} 1 \cdot \mathrm{D} 3}\right) / 3 \\
& E_{\mathrm{B} 3}=\left(P_{\mathrm{A} 1 . \mathrm{B} 3 . \mathrm{C} 3 \cdot \mathrm{D} 3}+P_{\mathrm{A} 2 \cdot \mathrm{B} 3 . \mathrm{C} 1 . \mathrm{D} 2}+P_{\mathrm{A} 3 \cdot \mathrm{B} 3 . \mathrm{C} 2 \cdot \mathrm{D} 1}\right) / 3 \\
& E_{\mathrm{C} 1}=\left(P_{\mathrm{A} 1 . \mathrm{B} 1 . \mathrm{C} 1 . \mathrm{D} 1}+P_{\mathrm{A} 2 \cdot \mathrm{B} 3 \cdot \mathrm{C} 1 . \mathrm{D} 2}+P_{\mathrm{A} 3 \cdot \mathrm{B} 2 . \mathrm{C} 1 . \mathrm{D} 3}\right) / 3 \\
& E_{\mathrm{C} 2}=\left(P_{\mathrm{A} 1 . \mathrm{B} 2 . \mathrm{C} 2 \cdot \mathrm{D} 2}+P_{\mathrm{A} 2 . \mathrm{B} 1 . \mathrm{C} 2 \cdot \mathrm{D} 3}+P_{\mathrm{A} 3 . \mathrm{B} 3 . \mathrm{C} 2 \cdot \mathrm{D} 1}\right) / 3 \\
& E_{\mathrm{C} 3}=\left(P_{\mathrm{A} 1 \cdot \mathrm{B} 3 \cdot \mathrm{C} 3 \cdot \mathrm{D} 3}+P_{\mathrm{A} 2 \cdot \mathrm{B} 2 \cdot \mathrm{C} 3 \cdot \mathrm{D} 1}+P_{\mathrm{A} 3 \cdot \mathrm{B} 1 \cdot \mathrm{C} 3 \cdot \mathrm{D} 2}\right) / 3 \\
& E_{\mathrm{D} 1}=\left(P_{\mathrm{A} 1 \cdot \mathrm{B} 1 \cdot \mathrm{C} 1 \cdot \mathrm{D} 1}+P_{\mathrm{A} 2 \cdot \mathrm{B} 2 \cdot \mathrm{C} 3 \cdot \mathrm{D} 1}+P_{\mathrm{A} 3 \cdot \mathrm{B} 3 \cdot \mathrm{C} 2 \cdot \mathrm{D} 1}\right) / 3 \\
& E_{\mathrm{D} 2}=\left(P_{\mathrm{A} 1 . \mathrm{B} 2 . \mathrm{C} 2 . \mathrm{D} 2}+P_{\mathrm{A} 2 . \mathrm{B} 3 . \mathrm{C} 1 . \mathrm{D} 2}+P_{\mathrm{A} 3 . \mathrm{B} 1 . \mathrm{C} 3 . \mathrm{D} 2}\right) / 3 \\
& E_{\mathrm{D} 3}=\left(P_{\mathrm{A} 1 \cdot \mathrm{B} 3 . \mathrm{C} 3 \cdot \mathrm{D} 3}+P_{\mathrm{A} 2 \cdot \mathrm{B} 1 . \mathrm{C} 2 \cdot \mathrm{D} 3}+P_{\mathrm{A} 3 \cdot \mathrm{B} 2 \cdot \mathrm{C} 1 . \mathrm{D} 3}\right) / 3
\end{aligned}
$$

\begin{tabular}{|c|c|c|c|c|c|}
\hline & \multicolumn{4}{|c|}{ Control factors } & \multirow{2}{*}{$\begin{array}{c}\text { Final } \\
\text { properties }\end{array}$} \\
\hline No. & A & B & $\mathrm{C}$ & D & \\
\hline 1 & $A_{1}$ & $B_{1}$ & $C_{1}$ & $D_{1}$ & $P_{\mathrm{A} 1 . \mathrm{B} 1 . \mathrm{C} 1 . \mathrm{D} 1}$ \\
\hline 2 & $A_{1}$ & $B_{2}$ & $C_{2}$ & $D_{2}$ & $P_{\mathrm{A} 1 . \mathrm{B} 2 . \mathrm{C} 2 . \mathrm{D} 2}$ \\
\hline 3 & $A_{1}$ & $B_{3}$ & $C_{3}$ & $D_{3}$ & $P_{\mathrm{A} 1 . \mathrm{B} 3 . \mathrm{C} 3 . \mathrm{D} 3}$ \\
\hline 4 & $A_{2}$ & $B_{1}$ & $C_{2}$ & $D_{3}$ & $P_{\mathrm{A} 2 . \mathrm{B} 1 . \mathrm{C} 2 . \mathrm{D} 3}$ \\
\hline 5 & $A_{2}$ & $B_{2}$ & $C_{3}$ & $D_{1}$ & $P_{\mathrm{A} 2 . \mathrm{B} 2 . \mathrm{C} 3 . \mathrm{D} 1}$ \\
\hline 6 & $A_{2}$ & $B_{3}$ & $C_{1}$ & $D_{2}$ & $P_{\mathrm{A} 2 . \mathrm{B} 3 \cdot \mathrm{C} 1 \cdot \mathrm{D} 2}$ \\
\hline 7 & $A_{3}$ & $B_{1}$ & $C_{3}$ & $D_{2}$ & $P_{\mathrm{A} 3 \text {.B1.C3.D2 }}$ \\
\hline 8 & $A_{3}$ & $B_{2}$ & $C_{1}$ & $D_{3}$ & $P_{\mathrm{A} 3 . \mathrm{B} 2 \cdot \mathrm{C} 1 . \mathrm{D} 3}$ \\
\hline 9 & $A_{3}$ & $B_{3}$ & $C_{2}$ & $D_{1}$ & $P_{\mathrm{A} 3 \text {.B3.C2.D1 }}$ \\
\hline
\end{tabular}

ここで, 制御因子 $\mathrm{A}$ の影響 $E_{\mathrm{A}}$ を計算しているときは, その他の制御因子 $\mathrm{B}, \mathrm{C}, \mathrm{D}$ の影響は平均化され，影響 $E_{\mathrm{A}}$ の中に含有される.これは, 制御因子 $\mathrm{B}, \mathrm{C}, \mathrm{D}$ の各影響 $E_{\mathrm{B}}, E_{\mathrm{C}}, E_{\mathrm{D}}$ についても同様である（ここで，環境変動 等で制御因子と最終特性值の間でばらつきが生じた場合には, その影響は上記の平均化された影響内にも含有さ れることになる．本報では，3.3 節に各制御因子の誤差の影響として検討寸る）。

最後に, 加法性によって全ての制御因子の水準組合せに対する最終特性值を計算できる. 加法性の一例として, 制御因子が A， B，C，Dの 4 つで，制御因子の水準がいずれも 3 つずつであるとして，例えばトライアルでは実 際に行っていない制御因子の水準組合せ $A_{3} \cdot B_{2} \cdot C_{3} \cdot D_{1}$ の条件について, その最終特性值 $P_{\mathrm{A} 3} \cdot \mathrm{B} 2 \cdot \mathrm{C} 3 \cdot \mathrm{D} 1$ の推定值

Table 1 Control factors in an experimental design

\begin{tabular}{|c|c|c|c|c|}
\hline \multicolumn{5}{|c|}{ Control factors } \\
\hline Name & $\mathrm{A}$ & $\mathrm{B}$ & $\mathrm{C}$ & $\mathrm{D}$ \\
\hline \multirow{3}{*}{ Levels } & $A_{1}$ & $B_{1}$ & $C_{1}$ & $D_{1}$ \\
\cline { 2 - 5 } & $A_{2}$ & $B_{2}$ & $C_{2}$ & $D_{2}$ \\
\cline { 2 - 5 } & $A_{3}$ & $B_{3}$ & $C_{3}$ & $D_{3}$ \\
\hline
\end{tabular}

Table 2 Orthogonal array and final properties in an experimental design 
は, 直交表の加法性に基づき, 対応する制御因子の影響の和と最終特性值の平均值から, 式(2)で計算できる.

$$
P_{\mathrm{A} 3 \cdot \mathrm{B} 2 \cdot \mathrm{C} 3 \cdot \mathrm{D} 1}=E_{\mathrm{A} 3}+E_{\mathrm{B} 2}+E_{\mathrm{C} 3}+E_{\mathrm{D} 1}-(4-1) P_{\mathrm{ave}}
$$

ここで, $P_{\mathrm{ave}}$ は最終特性值の平均值（表 2 の最終特性值の平均）である.

著者らがこの実験計画法で注目したのは，(1)各制御因子と影響 $E_{\mathrm{A}}$ を関数化できること (式(1))，(2)ある制御因 子について(1)を行っている際に，その対象制御因子以外の制御因子の影響が平均的に影響していること，(3加法 性によって全水準組合せに対してその最終特性值を推定できることの 3 つである.

\section{3.最適条件探査 プログラムの開 発}

\section{$3 \cdot 1$ 各制御因子と最終特性値の関数関係の探索方法}

表 2 の結果から，式(1)を使用して各制御因子とその最終特性值への影響 $E$ の関係のグラフを書くことができ る. 図 1 にその一例として, 制御因子 $\mathrm{A}$ の水準值と最終特性值への影響 $E_{\mathrm{A}}$ の関係のグラフを示す. このとき, 制御因子 $\mathrm{A}$ 以外の 3 つの制御因子 $\mathrm{B}, \mathrm{C}, \mathrm{D}$ の影響は平均的に影響している。同様にして, 各制御因子 $\mathrm{B}, \mathrm{C}, \mathrm{D}$ と最終特性值への影響 $E_{\mathrm{B}}, E_{\mathrm{C}}, E_{\mathrm{D}}$ の関係のグラフをそれぞれ示すことも可能である. この段階で, 各制御因子が 最終特性值への影響 $E$ に対してアナログ的にどのように影響しているかが把握できる. このとき，最終特性值へ の影響 $E$ に対する 1 つの制御因子の関数関係が, 他の複数制御因子の平均的な影響のもとで成立していることが 大きな特長である. また, 入力の各制御因子の各水準が等分布の值とは限らないので, この図によって各制御因 子の各水準值の影響力を物理的にイメージしやすくなり, 各水準值の影響の大小関係を適確な物理量として把握 することができる.

つぎに, 表 3 に示すように線形近似, 多項式近似, 対数近似, 指数近似, 累乗近似の 5 種類の近似方法でカー ブフィットを施すことによって，対象の制御因子が最終特性值に対して最も適確にその影響を表示している関数 関係を自動的に決定する. 具体的には, このカーブフィットで求めた関数関係式の中から, 各水準值での影響 $E_{\mathrm{x}}$ と関数関係で計算した值 $E_{\mathrm{x}}{ }^{\prime}$ の差の 2 乗和 $\Sigma_{\mathrm{x}=1 \sim \operatorname{level~number~}}\left(E_{\mathrm{x}}-E_{\mathrm{x}}{ }^{\prime}\right)^{2}$ が最小になる関数関係を決定する．また，プ ログラムに汎用性を持たせるために，この関数関係をマニュアルで選択できるようにした．このときは，プログ ラムの操作者による直感的な判断を行うことになる. また, 多項式近似では 3 次式までを標準表示し, また, 設 計者が任意の次数を選択できるようにもしてある.

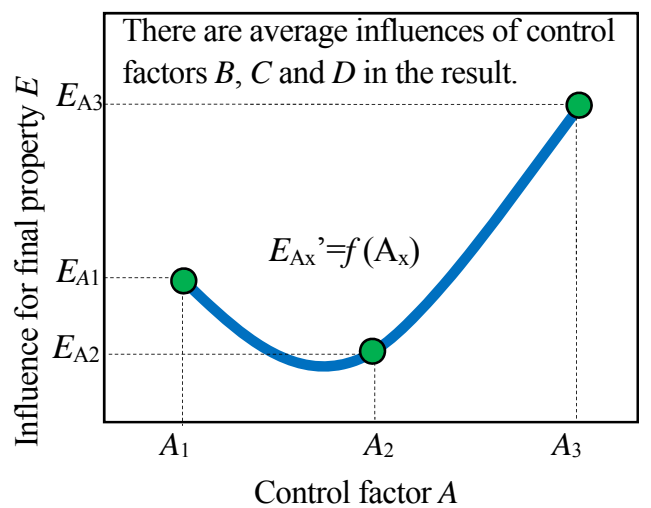

Table 3 Kinds of approximate curves regarding curve fit for first data in the program

\begin{tabular}{|c|l|}
\hline No. & Kinds of approximate curves \\
\hline 1 & Exponential approximation \\
\hline 2 & Linear approximation \\
\hline 3 & Logarithmic approximation (with degree) \\
\hline 4 & Polynomial approximation \\
\hline 5 & Radical approximation \\
\hline
\end{tabular}

Fig. 1 Relationship between the control factor $A$ and the final property $P$ in the experimental design.

つぎに, カーブフィット後の各制御因子と最終特性值の関数関係の探索方法については, 図 2 のフローチャー トにも示すように，得られた各関数関係が，制御因子 $\mathrm{A}$ の水準值 $A_{\mathrm{x}}$ とその影響 $E_{\mathrm{A}}$ の関数関係を $f\left(A_{\mathrm{x}}\right)$, 制御因 子 $\mathrm{B}$ の水準值 $B_{\mathrm{y}}$ とその影響 $E_{\mathrm{B}}$ の関数関係 を $g\left(B_{\mathrm{y}}\right)$, 制御因子 $\mathrm{C}$ の水準值 $C_{\mathrm{z}}$ とその影響 $E_{\mathrm{C}}$ の関数関係 $h\left(C_{\mathrm{z}}\right)$, 制 
御因子 $\mathrm{D}$ の水準值 $D_{\mathrm{w}}$ とその影響 $E_{\mathrm{D}}$ の関数関係を $i\left(D_{\mathrm{w}}\right)$, 各制御因子の影響の平均值 $P_{\mathrm{ave}}$ とすれば, 先の加法性 の式(2)は，式(3)のように書き換えることができる.

$$
P_{\mathrm{Ax} \cdot \mathrm{Bx} \cdot \mathrm{Cz} \cdot \mathrm{Dw}}=f\left(A_{\mathrm{x}}\right)+g\left(B_{\mathrm{y}}\right)+h\left(C_{\mathrm{z}}\right)+i\left(D_{\mathrm{w}}\right)-(4-1) P_{\mathrm{ave}}
$$

これは，離散化している水準值による加法性の式(2)を，連続している曲線に適用したものである。このように， 各制御因子の水準值の組合せと最終特性值 $P$ の関数関係を明らかにすることができる．最後に，この関数式（式 (3)）を使用して, 最適最終特性值とそれを達成するための各制御因子の最適水準值の組合せ（このとき各水淮值 の変動範囲はあらかじめ操作者がプログラムに入力）を，逐次代入法で計算することができる.

Start

Part I : Conventional experimental design

\begin{tabular}{|c|c|}
\hline Input : Control factors and these levels & \multirow{5}{*}{$\begin{array}{l}\text { Trial } \\
\begin{array}{l}\text { The desired final } \\
\text { property was } \\
\text { experiment or } \\
\text { calculated by } \\
\text { commercial CAE } \\
\text { simulation with } \\
\text { the orthogonal } \\
\text { array, then back to } \\
\text { the Part I. }\end{array}\end{array}$} \\
\hline $\begin{array}{l}\text { - Control factors were arranged in an orthogonal array. } \\
\cdot \text { This is compression of trial number. }\end{array}$ & \\
\hline $\begin{array}{l}\text { - Final properties were calculated for the all combinations using the each level of the } \\
\text { each control factor. }\end{array}$ & \\
\hline - Effective figures were calculated and displayed. & \\
\hline & \\
\hline
\end{tabular}

Part II: Optimum final property part

\begin{tabular}{|c|}
\hline $\begin{array}{l}\text { - Graphs of relationship between the levels of the each control factor and the final properties } \\
\text { were calculated and displayed. }\end{array}$ \\
\hline $\begin{array}{l}\text { - Curve fit using several approximate curves was performed, then optimum curves for the } \\
\text { each control factor were selected. } \Rightarrow \text { See Fig. } 1\end{array}$ \\
\hline $\begin{array}{l}\text { - Relationship between the final function } P \text { and the control factors } A, B, C \text {, and D is } \\
\text { cleared such as eq. ( } 3 \text { ) }\end{array}$ \\
\hline - Optimum final property with each optimum level value were calculated by equation (3). \\
\hline
\end{tabular}

Fig. 2 Flow chart of the program for calculation regarding the optimum final property with each optimum level value.

上記のアルゴリズムの評価ために, 制御因子 $\mathrm{A}, \mathrm{B}, \mathrm{C}$ と最終特性值 $P_{\mathrm{A} \cdot \mathrm{B} \cdot \mathrm{C}}$ の因果関係が，式(4)で示される構 造式であると仮定してデータを作成し，本アルゴリズムでこの構造式を解明できるかどうかを評価した.

$$
P_{\mathrm{A} \cdot \mathrm{B} \cdot \mathrm{C}}=A^{2}+9 A-B^{2}-3 B+5 C-46
$$

表 4 に使用した制御因子とその水準值，表 5 にそれらを記入した L9 直交表をそれぞれ示す．表中には，各制御 因子の各水準值組合せで構造式(4)を使用して計算した最終特性值 $P_{(4)}$ も示してある. 図 3 には，表 5 の最終特性 值 $P_{(4)}$ と式(1)から求めた最終特性值への影響 $E$ と制御因子の水準值の関係のグラフである. 自動のカーブフィッ 卜作業によって求めた関係式も図中に示してある. また, 図 3 の題目中には図 3 中の関係式 $f\left(A_{\mathrm{x}}\right), g\left(B_{y}\right), h\left(C_{z}\right)$ 
と式(3)から計算した各制御因子の水準值組合せと最終特性值 $P$ の関数関係も示寸.この関数関係は式(4)の構造 式と同じであり，本手法によって使用した構造式を完全に探索できている.

つぎに，式(5)に示す指数関数を含む構造式を用いて，上記のアルゴリズムの評価を行う。ここでも，表 4 の 制御因子とその水準值を流用した.

$$
P_{\text {A B B C }}=6 \mathrm{e}^{0.1 A}+2 B^{2}+5 B+6 C
$$

表 5 に L9 直交表に準じた各制御因子の各水準值組合せで, 構造式(5)を使用して計算した最終特性值 $P_{(5)}$ も示し てある. 図 4 は, 表 5 の最終特性值 $P_{(5)}$ と式(1)から求めた最終特性值への影響 $E$ と制御因子の水準值の関係のグ

Table 4 Control factors

\begin{tabular}{|c|c|c|c|}
\hline \multicolumn{4}{|c|}{ Control factors } \\
\hline Name & A & B & C \\
\hline Level 1 & 40 & 8 & 5 \\
\hline Level 2 & 50 & 12 & 5.5 \\
\hline Level 3 & 60 & 16 & 6 \\
\hline
\end{tabular}

Table 5 Orthogonal table and final properties

\begin{tabular}{|c|c|c|c|r|r|}
\hline L9 & A & B & C & \multicolumn{1}{c|}{$P_{(4)}$} & \multicolumn{1}{c|}{$P_{(5)}$} \\
\hline 1 & 40 & 8 & 5 & 1851 & 525.589 \\
\hline 2 & 40 & 12 & 5.5 & 1761.5 & 708.589 \\
\hline 3 & 40 & 16 & 6 & 1640 & 955.589 \\
\hline 4 & 50 & 8 & 5.5 & 2843.5 & 1091.479 \\
\hline 5 & 50 & 12 & 6 & 2754 & 1274.479 \\
\hline 6 & 50 & 16 & 5 & 2625 & 1512.479 \\
\hline 7 & 60 & 8 & 6 & 4036 & 2624.573 \\
\hline 8 & 60 & 12 & 5 & 3939 & 2798.573 \\
\hline 9 & 60 & 16 & 5.5 & 3817.5 & 3045.573 \\
\hline
\end{tabular}

$※ P_{(4) \text { ave }}=2807.5 \quad P_{(5) \text { ave }}=1615.214$

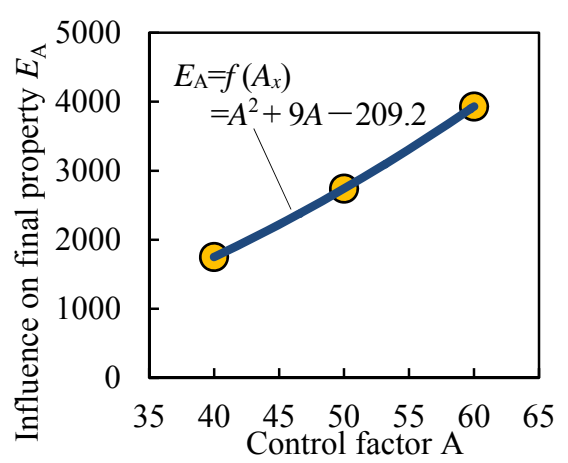

(a) Control factor $\mathrm{A}$
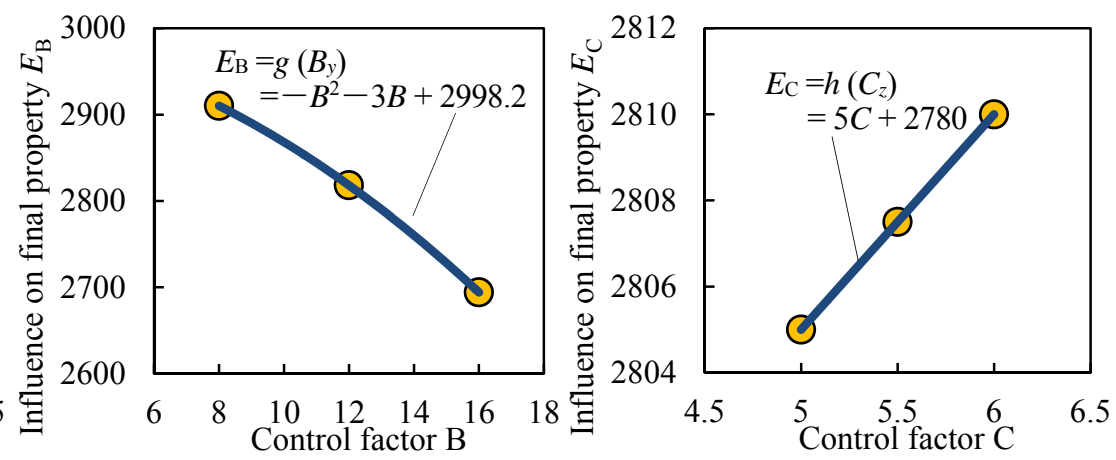

(b) Control factor B

(c) Control factor $\mathrm{C}$

Fig. 3 Relationship between the control factors A, B, C and the final property $P$ using the experimental design Structural formula (5) $\quad: P_{\text {A.B.C }}=A^{2}+9 A-B^{2}-3 B+5 C-46$,

Calculated formula (5)' $\quad: P_{\text {A.B.C }}=A^{2}+9 A-B^{2}-3 B+5 C-46$

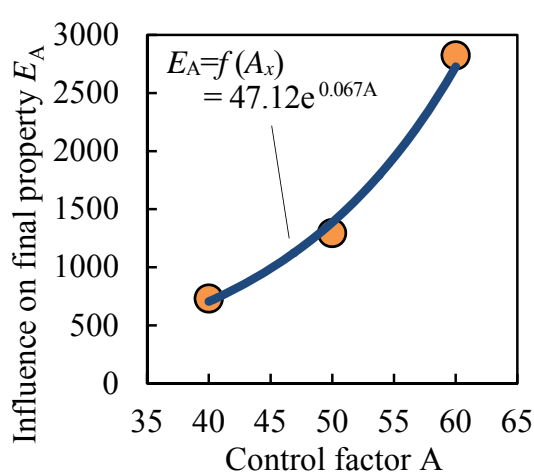

(a) Control factor $\mathrm{A}$

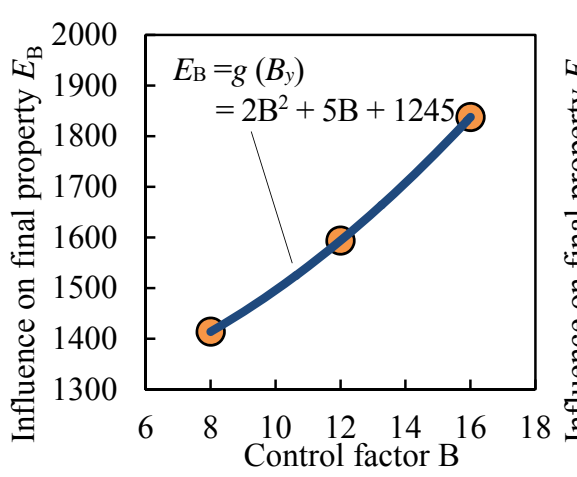

(b) Control factor B

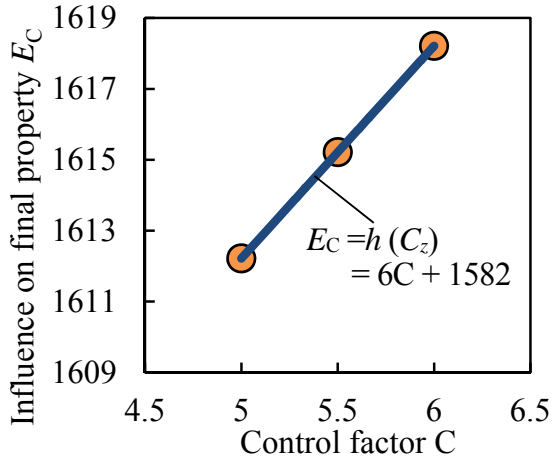

(c) Control factor $\mathrm{C}$

Fig. 4 Relationship between the control factors A, B, C and the final property $P$ using the experimental design

Structural formula (6) $\quad: P_{\text {A.B.C }}=6 \mathrm{e}^{0.1 A}+2 B^{2}+5 B+6 C, \quad$ and $P_{(6) \text { ave }}=1615.214$

Calculated formula (6)' $\quad: P_{\text {A.B.C }}=47.12 \mathrm{e}^{0.067 A}+2 B^{2}+5 B+6 C-402.337, \quad$ and $P_{(6) \text { ave }}=1605.753$ 
Table 6 Evaluation results using $1^{\text {st }}$ model

\begin{tabular}{|c|c|c|c|c|c|c|}
\hline & No. & $\begin{array}{l}\text { Structural formula of relationship between } \\
\text { the final property and the control factors. } \\
P_{\text {structural formula }}\end{array}$ & $\begin{array}{l}\text { Calculated formula using our algorithm. } \\
P_{\text {A.B.C }}\end{array}$ & $\begin{array}{l}\text { Error } \\
\%\end{array}$ & $\begin{array}{l}\text { Error } \\
\% \\
\text { (level } \\
\text { value } \\
\times 0.1 \text { ) }\end{array}$ & $\begin{array}{l}\text { Error } \\
\% \\
\text { (level } \\
\text { value } \\
\times 10 \text { ) }\end{array}$ \\
\hline \multirow{5}{*}{ 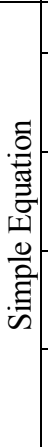 } & 1 & $P_{\mathrm{A} \cdot \mathrm{B} \cdot \mathrm{C}}=4.32 \mathrm{~A}-2.83 \mathrm{~B}+0.334 \mathrm{C}-31.57$ & $P_{\mathrm{A} \cdot \mathrm{B} \cdot \mathrm{C}^{\prime}}=4.32 \mathrm{~A}-2.83 \mathrm{~B}+0.334 \mathrm{C}-31.57$ & 0.00 & 0.00 & 0.00 \\
\hline & 2 & $\begin{aligned} P_{\mathrm{A} \cdot \mathrm{B} \cdot \mathrm{C}}= & 16.43 \ln (\mathrm{A})-8.823 \ln (\mathrm{B}) \\
& +\mathrm{C}^{2}+0.838\end{aligned}$ & $\begin{aligned} P_{\text {A.B.C }}= & 16.43 \ln (\mathrm{A})-8.823 \ln (\mathrm{B}) \\
& +\mathrm{C}^{2}+0.838\end{aligned}$ & 0.00 & 0.00 & 0.00 \\
\hline & 3 & $\begin{aligned} P_{\mathrm{A} \cdot \mathrm{B} \cdot \mathrm{C}}= & 2.68 \exp (0.097 \mathrm{~A})+3.54 \mathrm{~B} \\
& -1.2 \exp (0.96 \mathrm{C})-42.1\end{aligned}$ & $\begin{aligned} P_{\mathrm{A} \cdot \mathrm{B} \cdot \mathrm{C}^{\prime}=}= & 2.57 \exp (0.098 \mathrm{~A})+3.54 \mathrm{~B} \\
& -458 \exp (-0.0006 \mathrm{C})-498.9\end{aligned}$ & 0.13 & & \\
\hline & 4 & $P_{\mathrm{A} \cdot \mathrm{B} \cdot \mathrm{C}}=1.89 \mathrm{~A}^{1.32}+3.2 \mathrm{~B}^{0.73}-0.27 \mathrm{C}^{3.02}+4.32$ & $\begin{aligned} P_{\text {A.B.C }}= & 1.158 \mathrm{~A}^{1.425}+276.8 \mathrm{~B}^{0.044} \\
& +668.7 \mathrm{C}^{-0.45}-308.9\end{aligned}$ & 0.37 & 0.00 & \\
\hline & 5 & $\begin{aligned} P_{\mathrm{A} \cdot \mathrm{B} \cdot \mathrm{C}}= & 1.71 \mathrm{~A}^{2}-12.76 \mathrm{~A}+5.223 \mathrm{~B}^{2} \\
& -12.11 \mathrm{~B}-21.9 \mathrm{C}^{2}+1.02 \mathrm{C}+3.18\end{aligned}$ & $\begin{aligned} P_{\text {A.B.C' }}= & 1.71 \mathrm{~A}^{2}-12.76 \mathrm{~A}+5.223 \mathrm{~B}^{2} \\
& -12.11 \mathrm{~B}-21.9 \mathrm{C}^{2}+1.02 \mathrm{C}+3.18\end{aligned}$ & 0.00 & 0.37 & 0.00 \\
\hline \multirow{10}{*}{ 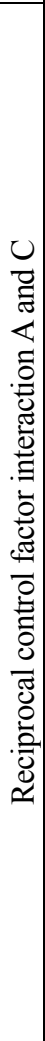 } & 6 & $P_{\mathrm{A} \cdot \mathrm{B} \cdot \mathrm{C}}=\mathrm{AC}+3 \mathrm{~A}-5 \mathrm{~B}+\mathrm{C}^{2}$ & $\begin{aligned} P_{\text {A.B.C }}= & 8.5 \mathrm{~A}+0.156 \mathrm{~B}^{2}-9.375 \mathrm{~B} \\
& +\mathrm{C}^{2}+50 \mathrm{C}-246.713\end{aligned}$ & 0.59 & 0.19 & 0.73 \\
\hline & 7 & $P_{\mathrm{A} \cdot \mathrm{B} \cdot \mathrm{C}}=\mathrm{C} \ln (\mathrm{A})-15 \mathrm{~B}^{2}+1000$ & $\begin{aligned} P_{\mathrm{A} \cdot \mathrm{B} \cdot \mathrm{C}^{\prime}=}= & 5.5 \ln (\mathrm{A})-2.997 \mathrm{~B}^{2}-0.081 \mathrm{~B} \\
& +3.898 \mathrm{C}+979.1\end{aligned}$ & 0.01 & 0.00 & 0.00 \\
\hline & 8 & $P_{\mathrm{A} \cdot \mathrm{B} \cdot \mathrm{C}}=-\mathrm{A}^{2}+12 \mathrm{AC}-10 \mathrm{~B}+\exp (\mathrm{C} / \mathrm{A})$ & $\begin{aligned} P_{\mathrm{A} \cdot \mathrm{B} \cdot \mathrm{C}^{\prime}=} & -\mathrm{A}^{2}+98.99 \mathrm{~A}+2.812 \mathrm{~B}^{2} \\
& -82.74 \mathrm{~B}+900 \mathrm{C}-4438.52\end{aligned}$ & 1.77 & 2.08 & 1.74 \\
\hline & 9 & $P_{\mathrm{A} \cdot \mathrm{B} \cdot \mathrm{C}}=4 \mathrm{~B}^{2}-32 \mathrm{~A} /(\mathrm{C}+15)-\ln (\mathrm{B})+5 \mathrm{C}$ & $\begin{aligned} P_{\text {A.B.C' }}= & -1.561 \mathrm{~A}+4.015 \mathrm{~B}^{2}-0.514 \mathrm{~B} \\
& -0.185 \mathrm{C}^{2}+10.85 \mathrm{C}-523.5\end{aligned}$ & 0.05 & 0.47 & 0.00 \\
\hline & 10 & $P_{\mathrm{A} \cdot \mathrm{B} \cdot \mathrm{C}}=\mathrm{C}^{3} / 4 \mathrm{~A}-3 \mathrm{~B}+\mathrm{AC}+240$ & $\begin{aligned} P_{\mathrm{A} \cdot \mathrm{B} \cdot \mathrm{C}^{\prime}=}= & 5.482 \mathrm{~A}+0.155 \mathrm{~B}^{2}-7.343 \mathrm{~B} \\
& +0.084 \mathrm{C}^{2}+0.155 \mathrm{C}-5.338\end{aligned}$ & 0.48 & 0.01 & 0.83 \\
\hline & 11 & $P_{\mathrm{A} \cdot \mathrm{B} \cdot \mathrm{C}}=1.5^{\mathrm{C}} \mathrm{A}+\exp (\mathrm{B} / 2)-5 \mathrm{~A}+\mathrm{C} 2-75$ & $\begin{aligned} P_{\mathrm{A} \cdot \mathrm{B} \cdot \mathrm{C}^{\prime}=} & 4.428 \mathrm{~A}+70.18 \mathrm{~B}^{2}-1321 \mathrm{~B} \\
& +39.35 \mathrm{C}^{2}-232 \mathrm{C}+6176\end{aligned}$ & 2.24 & 0.10 & 0.00 \\
\hline & 12 & $P_{\mathrm{A} \cdot \mathrm{B} \cdot \mathrm{C}}=\ln (\mathrm{AC})+\mathrm{C}^{2} / \mathrm{A}-\sqrt{\mathrm{AC}}-4 \mathrm{~B}+125$ & $\begin{aligned} P_{\mathrm{A} \cdot \mathrm{B} \cdot \mathrm{C}^{\prime}}= & -7.82 \ln (\mathrm{A})-0.002 \mathrm{~B}^{2} \\
& -3.919 \mathrm{~B}-6 \ln (\mathrm{C})+154.8\end{aligned}$ & 0.20 & 0.00 & 0.09 \\
\hline & 13 & $\begin{aligned} P_{\mathrm{A} \cdot \mathrm{B} \cdot \mathrm{C}}=(\mathrm{A} / 10)^{\mathrm{C} / 3}+\mathrm{A} / \mathrm{C}+(\mathrm{A}-2 \mathrm{C}) & \\
& -\ln (5 \mathrm{~B})-25\end{aligned}$ & $\begin{aligned} P_{\mathrm{A} \cdot \mathrm{B} \cdot \mathrm{C}^{\prime}=}= & 0.006 \mathrm{~A}^{2}+5.775 \mathrm{~A}+0.232 \mathrm{~B}^{2} \\
& -6.569 \mathrm{~B}+1.227 \mathrm{C}^{2}+23.09 \mathrm{C} \\
& -213.6\end{aligned}$ & 1.99 & 0.36 & $\begin{array}{l}9.0 \\
\times 10^{6}\end{array}$ \\
\hline & 14 & $P_{\mathrm{A} \cdot \mathrm{B} \cdot \mathrm{C}}=\exp (3 \mathrm{C} / \mathrm{A}) \times \mathrm{A} / 5+7 \mathrm{~B}+\mathrm{AC}-0.5 \mathrm{~B}^{2}$ & $\begin{aligned} P_{\mathrm{A} \cdot \mathrm{B} \cdot \mathrm{C}^{\prime}=}= & 5.653 \mathrm{~A}-0.344 \mathrm{~B}^{2}+2.644 \mathrm{~B} \\
& +0.026 \mathrm{C}^{2}+50.55 \mathrm{C}-245.3\end{aligned}$ & 0.87 & 0.18 & 1.18 \\
\hline & 15 & $\begin{aligned} P_{\mathrm{A} \cdot \mathrm{B} \cdot \mathrm{C}}= & \mathrm{AC} C^{1.85}-15 \mathrm{~A}+(\mathrm{B}-10)^{2} \\
& +130-\ln (\mathrm{A} / \mathrm{C})\end{aligned}$ & $\begin{aligned} & P_{\text {A.B.C }}= 8.485 \mathrm{~A}+2.183 \mathrm{~B}^{2}-53.38 \mathrm{~B} \\
&+0.655 \mathrm{C}^{3.95}-121.9 \\
&\end{aligned}$ & 3.49 & 0.02 & 1.54 \\
\hline \multirow{3}{*}{ 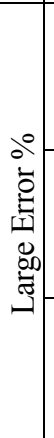 } & 16 & $\begin{aligned} P_{\mathrm{A} \cdot \mathrm{B} \cdot \mathrm{C}}= & \exp (\mathrm{A} / \mathrm{C})-0.7 \mathrm{~A}^{2}+13.4 \mathrm{~B} \\
& +55 \mathrm{C}-211\end{aligned}$ & $\begin{aligned} P_{\mathrm{A} \cdot \mathrm{B} \cdot \mathrm{C}^{\prime}=}= & 0.359 \exp (0.025 \mathrm{~A})-2347 \mathrm{~B}^{2} \\
& +5.8 \times 10^{4} \mathrm{~B}+5.7 \times 10^{4} \mathrm{C}^{2} \\
& -6.8 \times 10^{4} \mathrm{C}-5.1 \times 10^{4}\end{aligned}$ & 1017 & 501.0 & $2 \times 10^{47}$ \\
\hline & 17 & $\begin{aligned} P_{\mathrm{A} \cdot \mathrm{B} \cdot \mathrm{C}}= & 0.05 \mathrm{~A}^{\mathrm{C}}-2 \mathrm{~B}^{2}-11 \mathrm{~B}+0.5 \mathrm{~A}^{2} \\
& -32 \mathrm{C}+1205\end{aligned}$ & $\begin{aligned} P_{\mathrm{A} \cdot \mathrm{B} \cdot \mathrm{C}^{\prime}=} & 8205 \mathrm{~A}^{2}-8.7 \times 10^{5} \mathrm{~A}+5.1 \times 10^{4} \mathrm{~B}^{2} \\
& -1.4 \times 10^{6} \mathrm{~B}+3.2 \times 10^{6} \mathrm{C}^{2} \\
& -3.6 \times 10^{7} \mathrm{C}+1.4 \times 10^{8}\end{aligned}$ & 85.8 & 0.55 & $\begin{array}{l}1.0 \\
\times 10^{118}\end{array}$ \\
\hline & 18 & $P_{\mathrm{A} \cdot \mathrm{B} \cdot \mathrm{C}}=5 \mathrm{AC}^{\mathrm{A} / 2 \mathrm{C}}-12 \mathrm{AC}-35 \mathrm{~B}^{2}+420$ & $\begin{aligned} P_{\text {A.B.C }}= & 1.2 \times 10^{4} \mathrm{~A}^{2}-1.0 \times 10^{6} \mathrm{~A} \\
& -3.4 \times 10^{4} \mathrm{~B}^{2}+8.6 \times 10^{5} \mathrm{~B} \\
& +3.5 \times 10^{5} \mathrm{C}^{2}-4.8 \times 10^{6} \mathrm{C}+1.7 \times 10^{6}\end{aligned}$ & 130.9 & 0.10 & $\begin{array}{l}7.8 \\
\times 10^{4}\end{array}$ \\
\hline
\end{tabular}

$※$ Error $\%=\left(\Sigma_{\mathrm{L} 1 \sim \mathrm{L} 9}\left|P_{\text {structural formula }}-E q_{(4)}\right| \div P_{\text {structural formula }} \times 100\right) \div 9$

: Error $\%>50 \% \quad \square:$ Error $\%>1 \% \quad \square:$ Error $\% \leq 1 \%$ 
ラフである. 自動のカーブフィット作業によって求めた式も図中に示してある. また, 図 4 の題目中には図 4 中 の各関係式 $f\left(A_{\mathrm{x}}\right), g\left(B_{\mathrm{y}}\right), h\left(C_{\mathrm{z}}\right)$ と式(3)から計算した各制御因子の水準值の組合せと最終特性值 $P$ の関数関係と, それを使用して計算した最終特性值の平均值 $P_{(\text {() ave }}$ も示してある.これらの関数式には指数関数が含まれている ので，指数関数の中に含まれる各制御因子の影響の平均值 $E_{\mathrm{ave}}$ の影響を分離することが困難であったた め, 式(5)と計算された関数式では指数関数の部分では多少異なる形となっているが, 定数值が指数関数内で処理 されているだけなので, 式(5)と計算された関数式でそれぞれ計算した最終特性值の平均值 $P_{(6) \text { ave }}$ と $P_{(6) \text { ave }}$ の間で 0.6\%以下の違いであり, 大きな影響はなかった.

その他の複雑な構造式を使用した評価結果を表 6 に示寸. 表 4 の制御因子とその水準值, および表 5 の L9 直 交表を使用した。 誤差 Error \%は，評価のために使用した構造式 $P_{\text {structural formula }}$ と計算で求めた関係式 $P_{\mathrm{A} \cdot \mathrm{B} \cdot \mathrm{C}}$ 'の差を 構造式 $P_{\text {structural formula }}$ で除し, それを百分率で表し, さらに, 同様の計算を表 5 の L9 直交表に従って 9 通りの計算, 平均した值である（誤差 Error \% $\left.\%\left(\Sigma_{\mathrm{L} 1 \sim \mathrm{L} 9}\left|P_{\text {structural formula }}-P_{\mathrm{A} \cdot \mathrm{B} \cdot \mathrm{C}}{ }^{\prime}\right| \div P_{\text {structural formula }} \times 100\right) \div 9\right)$ 。また，表 6 には， 表 4 の各水準值を全て $1 / 10$ 倍にした場合と, 全て 10 倍にした場合の Error \%の計算結果も示してある（これは， 高精度な計算結果を得るためのスケーリングではなく, 制御因子の水準值の大小関係が計算結果に与える影響を 検討するために行った）。構造式の中に，指数関数もしくは累乗関数が含まれ，さらに，定数值が含まれている 場合には, 本報のアルゴリズムでは各関数と定数值を分離することが困難であるため, 最初に使用した構造式と 計算した制御因子と最終特性值の関係式は多少係数值が異なっている. しかし，それを使用して計算した最終特 性值の誤差は 1\%以下であり, 実用的に利用可能であると考えられる. また, 構造式中に交互作用 (Tanabe, 2017) があり, その交互作用の項の影響が大きい場合には, 各制御因子の水準值の組合せと最終特性值 $P$ の関数関係を 明らかにすることが困難であった，そのため，本手法は交互作用がない場合を前提条件として使用することにす る（本手法は交互作用がある場合には困難である）.

\section{$3 \cdot 2$ 最適最終特性値を得るための各制御因子の最適水準値の決定}

式(3)を使用して最適な最終特性值 $P$ を得るための制御因子 A, B , C, D の各水準值を決定する. 図 5 に示寸 ように, 最適最終特性值を得るために, 各制御因子の最適水準值を決定する. 具体的には, (1)各制御因子の関数 式の決定，(2)所望の最終特性值の入力（大，小，所望値), (3)物理的, 時間的, 地理的, 金銭的等の条件や, 特許 や作業的制約等を鑑み, 制御因子の可能変動範囲の入力, (4)逐次代入法による各制御因子の最適水淮値の決定, (5)式(2)を用いて各制御因子の各最適水準值を用いた場合の最適最終特性值を計算する。この計算は, 他の制御 因子を固定し，1つの制御因子を変化させ，最終特性值を計算している．同様の計算を各制御因子ついて行 い，その中から最終特性值の影響を調べている.また，これは交互作用がない場合を想定した場合の手順で ある.

これらのアルゴリズムを使用して, 先の図 2 のフローチャートに従って,「最適条件探査プログラム」のプログ ラムをC 言語で開発した.

(1)

\begin{tabular}{l}
\hline Relational formulas \\
between the each \\
control factor and \\
the final property \\
were decided. \\
\hline
\end{tabular}

(2)

Desired final property
was inputted.
(Maximum, Minimum
or desired value?).

(3) Approved changes for the each control factor were inputted.

Fig. 5 Procedure for calculation regarding the optimum final property with each optimum level value

\section{$3 \cdot 3$ 各制御因子と最終特性值の関数関係の探索精度}

ここでは, 前節で使用した構造式 (式(5))をべースにし, 式(6) のように各制御因子の水準值の中に誤差 $\pm \Delta A s$, 


$$
\begin{array}{r}
F_{\mathrm{L}}=6 \mathrm{e}^{0.1\left(\mathrm{~A}_{\mathrm{s}}^{ \pm} \pm \Delta A_{\mathrm{S}}\right)}+2\left(B_{\mathrm{T}} \pm \Delta B_{\mathrm{T}}\right)^{2}+5\left(B_{\mathrm{T}} \pm \Delta B_{\mathrm{T}}\right)+6\left(C_{\mathrm{M}} \pm \Delta C_{\mathrm{M}}\right) \\
\text { (Where } \mathrm{L}=1 \sim 9 ; \mathrm{S}, \mathrm{T} \text { and } \mathrm{M}=1,2 \text { or } 3)
\end{array}
$$

$\pm \Delta B_{\mathrm{T}}, \pm \Delta C_{\mathrm{M}}$ を追加した，その後，最終特性值の関数関係がこれらの誤差によってどのような影響を受けるか を評価した．表 4 の制御因子とその水準值，および表 5 の L9 直交表を使用した. 制御因子 A， B，Cに含まれる 誤差として，式(6)の $\Delta A_{\mathrm{S}}, \Delta B_{\mathrm{T}}, \Delta C_{\mathrm{M}}$ がそれぞれ $\pm 1 \%, \pm 3 \%, \pm 5 \%, \pm 10 \%$ の範囲内であると仮定して，誤差の影 響をランダムに与え（10 回）, 最終特性值 $P$ 'の関数関係式をそれぞれ計算し, 誤差の項のない構造式（式(5)）の

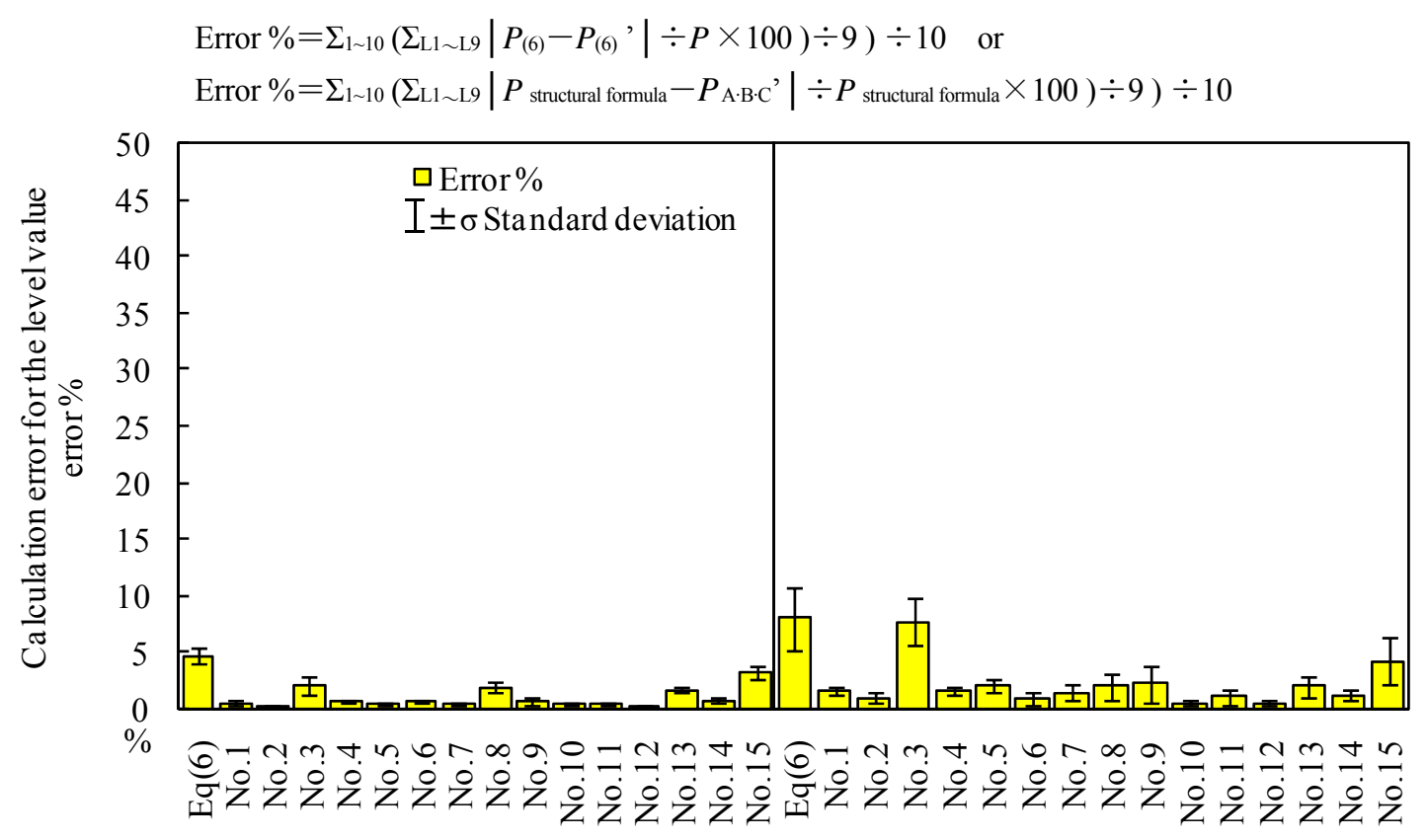

(a) Level value error $1 \%$

(b) Level value error $3 \%$

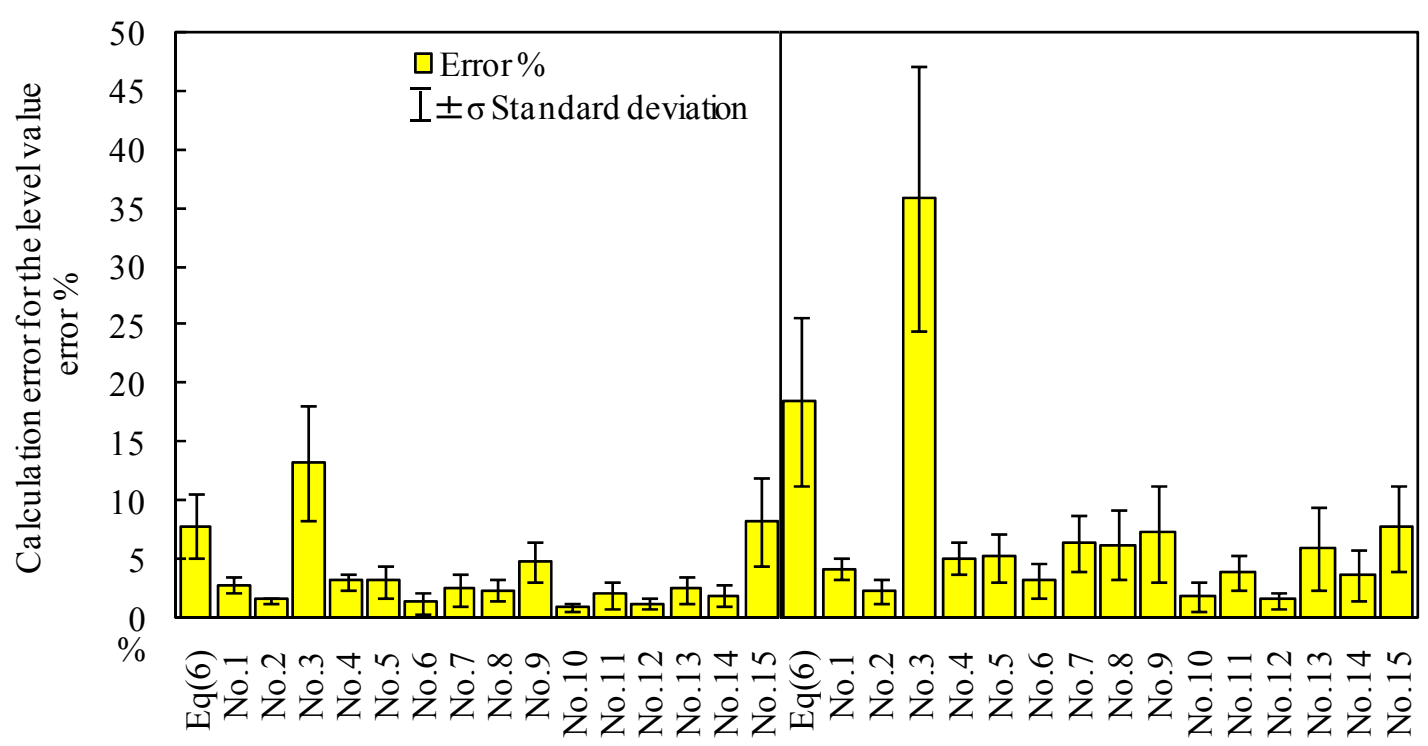

(c) Level value error $5 \%$

(d) Level value error $10 \%$

Fig. 6 Relationship between the control factors A, B, C and the final property $P$ using the experimental design (Structural formula (6): $\mathrm{P}_{\mathrm{A} \cdot \mathrm{B} \cdot \mathrm{C}}=6 \mathrm{e}^{0.1 \mathrm{~A}}+2 \mathrm{~B}^{2}+5 \mathrm{~B}+6 \mathrm{C}$, and No.1 -15 in Table 6 ) 
最終特性值 $P$ と比較し，その計算誤差を求めた。精度は 10 回の計算の平均值と標準偏差で評価した. 同様の作 業を，表 6 に示寸 15 本の構造式 $P_{\text {structural formula }}$ に対して，最終特性值の関数関係式 $P_{\text {A.B.C. }}$ をそれぞれ計算し，その 計算誤差を各 10 回ずつ求め, 平均值と標準偏差での評価した結果を図 6 に示寸. 制御因子の水準值に含まれる 誤差が $3 \%$ 以下場合には精度よく推定ができているが，その誤差が $\pm 5 \%$ \%ると，計算誤差が $2 \%$ から $17 \%$ と大 きくなっている. そのため, 制御因子の水準值に誤差影響が大きく含まれる可能性がある場合には, トライアル 回数を増やして（N值を大きくして），水淮值の精度を上げることが必要と考える.

\section{4.強アルカリ水ミスト強制冷却システムの最適稼動条件探索（評価）}

\section{$4 \cdot 1$ 評価に使用する強アルカリミスト強制冷却における見かけ上の熱伝達率モデルの説明}

開発した最適条件探索プログラムを評価するために, 著者らの先の研究（Tanabe, 2014）「強アルカリ水に空気 を混合することによる, 見かけ上の熱伝達率を向上させる研究」で, 見かけ上の熱伝達率の計算式を推定するた めに本手法を利用し，本手法の有効性を評価した。

先の研究では, 強アルカリ水ミストを作成寸るために図 7 に示寸自作ノズルで, 図 8 に示寸実験装置で見かけ 上の熱伝達率を測定している.

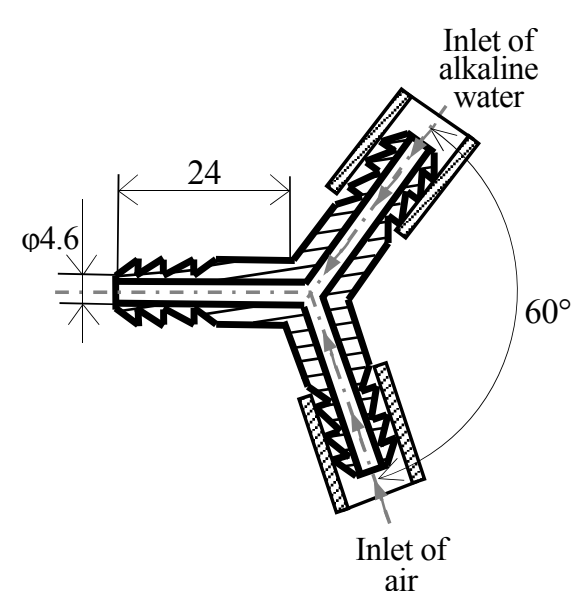

Fig. 7 Schematic view of nozzle for mist of strong alkaline water

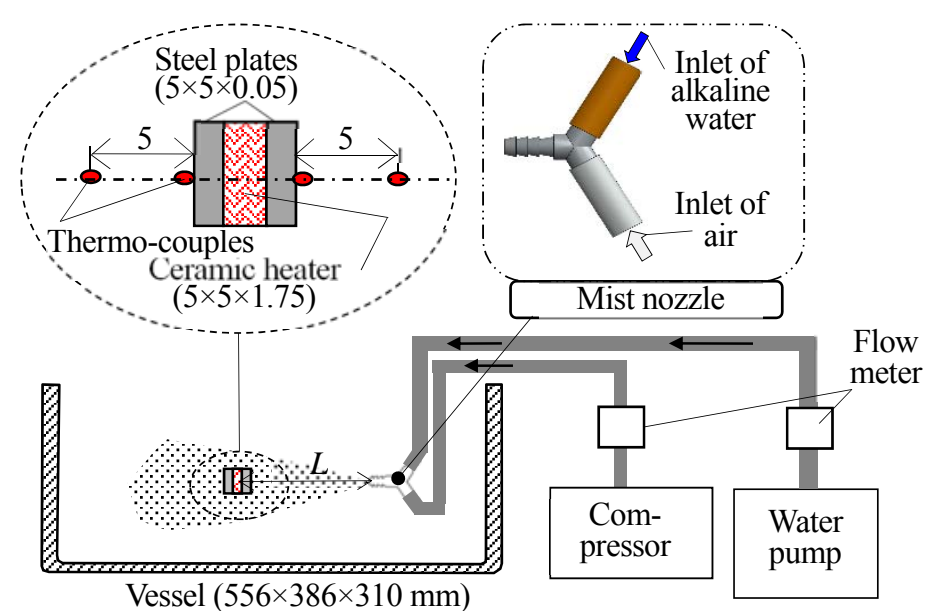

Fig. 8 Experimental set-up for measuring heat transfer coefficient regarding mist of strong alkaline water

また，この強アルカリ水ミストの冷却能力を制御するために，見かけ上の熱伝達率モデル（式(7)）が構築され ている.この見かけ上の熱伝達率モデルは，まず，ミストの粘性係数と熱伝導率を 2 成分系混合気体の粘度推算 の式と Wassiljewa の式から求めた（磯村, 水巻，1959），(日本機械学会編，1993）。つぎに，これらの值とミスト の密度および比熱容量から, 動粘性係数と熱拡散率を求めた（植田, 1981）.さらに, ミストの断面積と流量から 流速を求めた. 以上の数值からレイノルズ数とプラントル数を算出し, 円柱に対する熱伝達率の関係式に適用寸 ることで, 気化熱現象を考慮した見かけ上の熱伝達率が計算できる（日本機械学会編，1986）. 最終的に見かけ上 の熱伝達率 $h$ は式(7)から算出が可能である.

$$
h=0.6 \frac{\lambda_{\text {water }}}{L} \operatorname{Re}^{0.58} \operatorname{Pr}^{0.4}
$$

$$
\operatorname{Re}=\frac{\left(Q_{\text {air }}+Q_{\text {water }}\right) \times\left\{\frac{Q_{\text {air }}}{Q_{\text {air }}+Q_{\text {water }}} \rho_{\text {air }}+\left(1-\frac{Q_{\text {air }}}{Q_{\text {air }}+Q_{\text {water }}}\right) \rho_{\text {water }}\right\}}{\mu_{\text {mist }} \times \pi\left\{\tan \frac{\varphi}{2}\right\}^{2}}
$$




$$
\begin{aligned}
& \operatorname{Pr}=\frac{\mu_{\text {mist }}\left\{\frac{\Psi \rho_{\text {air }} C_{\text {air }}}{\Psi \rho_{\text {air }}+(1-\Psi) \rho_{\text {water }}}+\frac{(1-\Psi) \rho_{\text {water }} C_{\text {water }}}{\Psi \rho_{\text {air }}+(1-\Psi) \rho_{\text {water }}}\right\}}{\frac{\lambda_{\text {air }} y_{\text {air }}}{y_{\text {air }}+\varphi_{1} y_{\text {water }}}+\frac{\lambda_{\text {water }} y_{\text {water }}}{y_{\text {water }}+\varphi_{2} y_{\text {air }}}} \\
& \mu_{\text {mist }}=\frac{\mu_{\text {air }}}{1+\frac{y_{\text {water }}\left\{1+\left(\mu_{\text {air }} / \mu_{\text {water }}\right)^{0.5}\left(M_{\text {water }} / M_{\text {air }}\right)^{0.25}\right\}^{2}}{4 y_{\text {air }}\left\{2+2\left(M_{\text {air }} / M_{\text {water }}\right)\right\}^{0.5}}}+\frac{\mu_{\text {water }}}{1+\frac{y_{\text {air }}\left\{1+\left(\mu_{\text {water }} / \mu_{\text {air }}\right)^{0.5}\left(M_{\text {air }} / M_{\text {water }}\right)^{0.25}\right\}^{2}}{4 y_{\text {water }}\left\{2\left(M_{\text {water }} / M_{\text {air }}\right)\right\}^{0.5}}} \\
& \Psi=\frac{Q_{\text {air }}}{Q_{\text {air }}+Q_{\text {water }}} \\
& y_{\text {air }}=\frac{Q_{\text {air }} \rho_{\text {air }} / M_{\text {air }}}{Q_{\text {air }} \rho_{\text {air }} / M_{\text {air }}+Q_{\text {water }} \rho_{\text {water }} / M_{\text {water }}} \\
& y_{\text {water }}=\frac{Q_{\text {water }} \rho_{\text {water }} / M_{\text {water }}}{Q_{\text {air }} \rho_{\text {air }} / M_{\text {air }}+Q_{\text {water }} \rho_{\text {water }} / M_{\text {water }}} \\
& \varphi_{1}=\frac{1}{4}\left\{1+\left(\frac{\mu_{\text {air }}}{\mu_{\text {water }}}\left(\frac{M_{\text {air }}}{M_{\text {water }}}\right)^{0.75} \frac{1+1.5 T_{\text {bair }} / T_{\text {water }}}{1+1.5 T_{\text {bwater }} / T_{\text {water }}}\right)^{0.5}\right\}^{2}\left(\frac{1+1.5\left(T_{\text {bari }} T_{\text {bwater }}\right)^{0.5} / T_{\text {water }}}{1+1.5 T_{\text {bair }} / T_{\text {water }}}\right) \\
& \varphi_{2}=\frac{1}{4}\left\{1+\left(\frac{\mu_{\text {water }}}{\mu_{\text {air }}}\left(\frac{M_{\text {water }}}{M_{\text {air }}}\right)^{0.75}\left(\frac{1+1.5 T_{\text {bwater }} / T_{\text {water }}}{1+1.5 T_{\text {bwater }} / T_{\text {water }}}\right)^{0.5}\right\}^{2}\left(\frac{1+1.5\left(T_{\text {bari }} T_{\text {bwater }}\right)^{0.5} / T_{\text {water }}}{1+1.5 T_{\text {bwater }} / T_{\text {water }}}\right)\right.
\end{aligned}
$$

ここで， $\lambda_{\text {water }}$ は水の熱伝導率 $[\mathrm{W} / \mathrm{m} ・ \mathrm{~K}] ， L$ は代表長さ $[\mathrm{m}] ， \operatorname{Re}$ はレイノルズ数，Pr $\operatorname{Pr}$ ぱラントル数， $\mu_{\mathrm{mist}}$ はミ スト粘性係数 $[\mathrm{Pa} ・ \mathrm{~s}] ， \Psi$ はボイド比， $y_{\text {air }}$ は空気モル分率， $y_{\text {water }}$ は水モル分率， $\varphi_{1}$ および $\varphi_{2}$ は結合係数， $\lambda_{\text {air }}$ は空 気熱伝導率 $[\mathrm{W} / \mathrm{m}$ K $] ， \rho_{\text {air }}$ は空気密度 $\left[\mathrm{kg} / \mathrm{m}^{3}\right] ， \rho_{\text {water }}$ は水密度 $\left[\mathrm{kg} / \mathrm{m}^{3}\right] ， \mu_{\text {air }}$ は空気粘性係数 $[\mathrm{Pa} ・ \mathrm{~s}] ， \mu_{\text {water }}$ は水粘 性係数 $[\mathrm{Pa} ・ \mathrm{~s}] ， M_{\text {air }}$ は空気分子量 $[\mathrm{kg} / \mathrm{mol}] ， M_{\text {water }}$ は水分子量 $[\mathrm{kg} / \mathrm{mol}] ， C_{\text {air }}$ は空気比熱容量 $[\mathrm{J} / \mathrm{kg} ・ \mathrm{~K}] ， C_{\mathrm{water}}$ は 水比熱容量 $[\mathrm{J} / \mathrm{kg} ・ \mathrm{~K}] ， T_{\text {bair }}$ は空気沸点 $[\mathrm{K}] ， T_{\text {bwater }}$ は水沸点 $[\mathrm{K}] ， Q_{\text {air }}$ は空気流量 $\left[\mathrm{m}^{3} / \mathrm{s}\right] ， Q_{\text {water }}$ は水流量 $\left[\mathrm{m}^{3} / \mathrm{s}\right]$, $L$ はノズル先端と冷却箘所の直線距離 $[\mathrm{m}] ， \varphi$ はノズル噴出角度 $\left.{ }^{\circ}\right] ， T_{\text {water }}$ は水温[K]である. この式(7)の計算精 度は，先の研究で，計算值と実験值の誤差は一 $27 \%$ 19\%であった．この誤差の原因については，計算の際にノ ズルの噴出口においてミストの粒子が均一に分散していると仮定しているが，実際のミストの噴射については均 一に分散しておらず，これにより誤差が生じたものと考えている.

本報では，この複雑な見かけ上の熱伝達率モデル（式(7)）を使用し，開発した最適条件探索プログラムを評価 することにした.

\section{$4 \cdot 2$ 本プログラムを用いた強アルカリミスト強制冷却システムの最適稼動条件の探索}

本プログラムの評価のために, 強アルカリ水ミスト強制冷却システムの最適稼動条件探索を行う。表 7 に制御 因子を示す. 前節の見かけ上の熱伝達率モデル (式(7)) の中で, 熱伝導率に大きな影響を及ぼす制御因子として,

Table 7 Control factors for evaluation

\begin{tabular}{|c|c|c|c|c|c|}
\hline Control factors & Level 1 & Level 2 & Level 3 & Level 4 & Level 5 \\
\hline Water flow rate $\ell / \mathrm{min}$ & 0.5 & 1.875 & 3.25 & 4.625 & 6 \\
\hline Air flow rate $\ell / \mathrm{min}$ & 20 & 25 & 30 & 35 & 40 \\
\hline${\text { Outlet area } \mathrm{m}^{2}}^{\circ}$ & $1.0 \times 10^{-5}$ & $1.5 \times 10^{-5}$ & $2.0 \times 10^{-5}$ & $2.5 \times 10^{-5}$ & $3.0 \times 10^{-5}$ \\
\hline Angle of injection $^{\circ}$ & 8 & 12 & 18 & 24 & 28 \\
\hline
\end{tabular}


Tanabe, Sohichiro Takahashi and Satoshi Takahashi, Transactions of the JSME (in Japanese), Vol.84, No.862 (2018)

Table 8 Orthogonal array and final properties in an experimental design

\begin{tabular}{|c|c|c|c|c|c|c|c|c|c|c|c|}
\hline \multicolumn{5}{|c|}{ Control factors } & \multirow{2}{*}{$\begin{array}{l}\text { Heat transfer } \\
\text { coefficient } \\
\text { (Experimental } \\
\text { results) }\end{array}$} & \multicolumn{5}{|c|}{ Control factors } & \multirow{2}{*}{$\begin{array}{l}\text { Heat transfer } \\
\text { coefficient } \\
\text { (Experimental } \\
\text { results) }\end{array}$} \\
\hline No. & $\begin{array}{c}\text { Water } \\
\text { flow rate } \\
\text { l/min } \\
\end{array}$ & $\begin{array}{l}\text { Air flow } \\
\text { rate } \\
\ell / \text { min } \\
\end{array}$ & $\begin{array}{c}\text { Outlet } \\
\text { area } \mathrm{m}^{2}\end{array}$ & $\begin{array}{l}\text { Angle of } \\
\text { injection }^{\circ}\end{array}$ & & No. & $\begin{array}{c}\text { Water } \\
\text { flow rate } \\
\text { l/min } \\
\end{array}$ & $\begin{array}{l}\text { Air flow } \\
\text { rate } \\
\ell / \text { min } \\
\end{array}$ & $\begin{array}{c}\text { Outlet } \\
\text { area } \mathrm{m}^{2}\end{array}$ & $\begin{array}{l}\text { Angle of } \\
\text { injection }^{\circ}\end{array}$ & \\
\hline 1 & 0.5 & 20 & $1.0 \times 10^{-5}$ & 12 & 8129.042 & 13 & 3.25 & 30 & $3.0 \times 10^{-5}$ & 15 & 14245.792 \\
\hline 2 & 0.5 & 25 & $1.5 \times 10^{-5}$ & 15 & 6690.322 & 14 & 3.25 & 35 & $1.0 \times 10^{-5}$ & 18 & 11683.393 \\
\hline 3 & 0.5 & 30 & $2.0 \times 10^{-5}$ & 18 & 5734.165 & 15 & 3.25 & 40 & $1.5 \times 10^{-5}$ & 21 & 9890.731 \\
\hline 4 & 0.5 & 35 & $2.5 \times 10^{-5}$ & 21 & 5049.007 & 16 & 4.625 & 20 & $2.5 \times 10^{-5}$ & 15 & 16553.956 \\
\hline 5 & 0.5 & 40 & $3.0 \times 10^{-5}$ & 24 & 4531.111 & 17 & 4.625 & 25 & $3.0 \times 10^{-5}$ & 18 & 13525.915 \\
\hline 6 & 1.875 & 20 & $1.5 \times 10^{-5}$ & 18 & 8483.119 & 18 & 4.625 & 30 & $1.0 \times 10^{-5}$ & 21 & 11409.836 \\
\hline 7 & 1.875 & 25 & $2.0 \times 10^{-5}$ & 21 & 7263.390 & 19 & 4.625 & 35 & $1.5 \times 10^{-5}$ & 24 & 9850.014 \\
\hline 8 & 1.875 & 30 & $2.5 \times 10^{-5}$ & 24 & 6358.902 & 20 & 4.625 & 40 & $2.0 \times 10^{-5}$ & 12 & 22558.824 \\
\hline 9 & 1.875 & 35 & $3.0 \times 10^{-5}$ & 12 & 14756.968 & 21 & 6 & 20 & $3.0 \times 10^{-5}$ & 21 & 12797.347 \\
\hline 10 & 1.875 & 40 & $1.0 \times 10^{-5}$ & 15 & 11639.933 & 22 & 6 & 25 & $1.0 \times 10^{-5}$ & 24 & 11023.928 \\
\hline 11 & 3.25 & 20 & $2.0 \times 10^{-5}$ & 24 & 7902.456 & 23 & 6 & 30 & $1.5 \times 10^{-5}$ & 12 & 25194.553 \\
\hline 12 & 3.25 & 25 & $2.5 \times 10^{-5}$ & 12 & 18194.806 & 24 & 6 & 35 & $2.0 \times 10^{-5}$ & 15 & 19586.816 \\
\hline & & & & & & 25 & 6 & 40 & $2.5 \times 10^{-5}$ & 18 & 15954.704 \\
\hline
\end{tabular}

$※ P_{(8) \text { ave }}=11960.361$

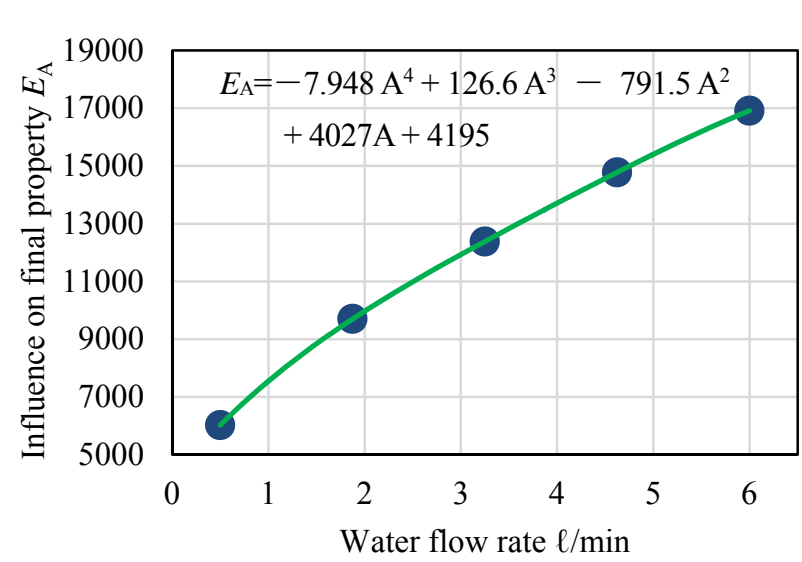

(a) Control factor A (Water flow rate)

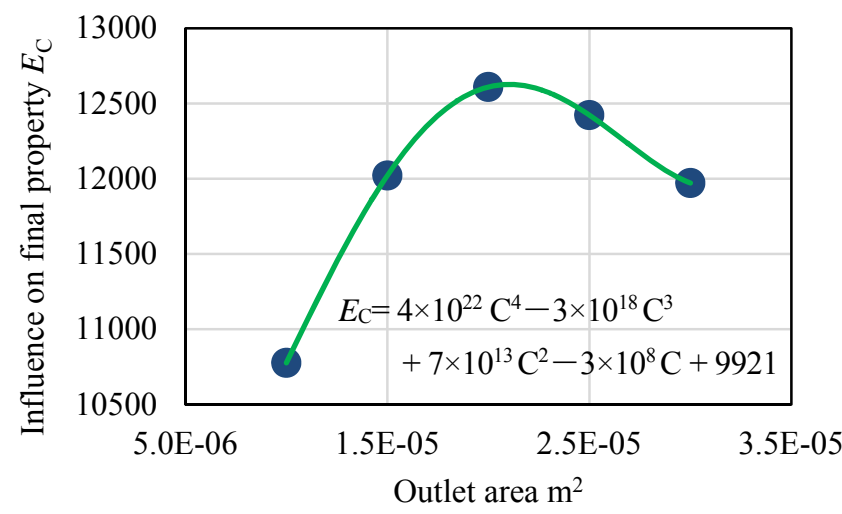

(b) Control factor $\mathrm{C}$ (Outlet area)

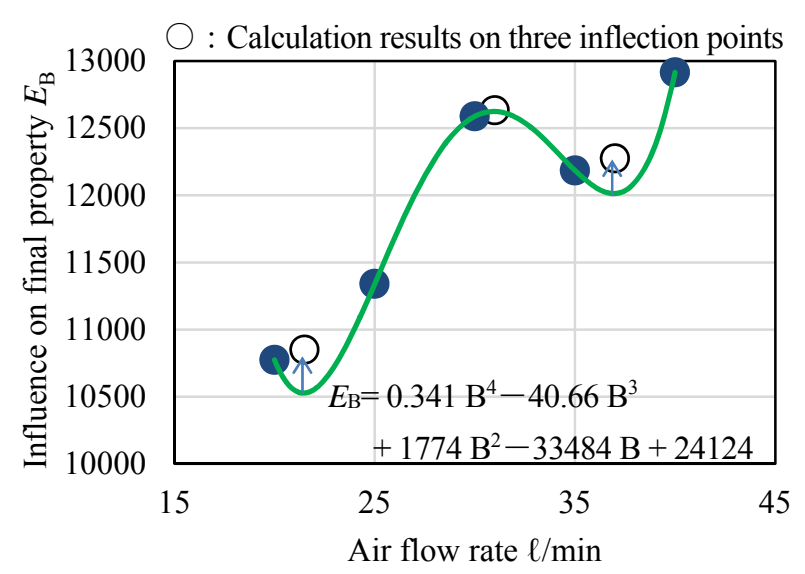

(b) Control factor B (Air flow rate)

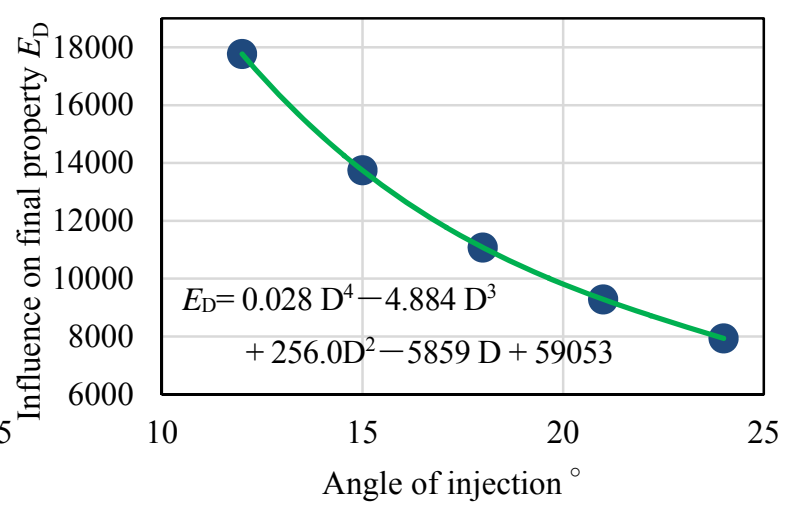

(d) Control factor D (Angle of injection)

Fig. 9 Relationship between the control factors A, B, C and the final property $P$ in the experiment. 


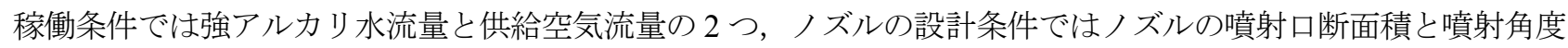
の 2 つの合計 4 つを使用する. 本報では, その他, ノズルと冷却箇所の距離 $(=50 \mathrm{~mm})$, 強アルカリ水温 $(=$ $\left.20^{\circ} \mathrm{C}\right)$ は固定した. 各制御因子の水準は，計算する見かけ上の熱伝達率モデルが高次になることを考え各 5 水準 とし，その水準值は実験装置の都合を考慮しながら，物理的最大值と最小值の間を 4 等分して設定した. 表 8 に 示すように, 表 7 の各制御因子の水準值を L25 直交表に従って割り付け, さらに, 前節の見かけ上の熱伝達率モ デル（式(7)）を使用して割り付けられた水準值の組合せのときの見かけ上の熱伝達率を計算した結果も示してあ る. カーブフィットでは, 多項式の 4 次までを次数として選択した.

つぎに, 図 9 に各制御因子 (強アルカリ水流量, 供給空気流量, ノズルの噴射口断面積, 噴射角度) と最終特 性值（見かけ上の熱伝達率）への影響の関係を示寸. 図中には自動のカーブフィットによって明らかにされた関 数式 (式(8)）を示す.このように, 各制御因子と最終特性值 $P$ への影響の関数関係を明らかにすることができた.

$$
\begin{aligned}
& E_{\mathrm{A}}=-7.95 A^{4}+126.6 A^{3}-791.5 A^{2}+4027 A+4196 \\
& E_{\mathrm{B}}=0.3414 B^{4}-40.66 B^{3}+1775 B^{2}-33484 B+241247 \\
& E_{\mathrm{C}}=4.182 \times 10^{22} C^{4}-3.084 \times 10^{18} C^{3}+6.812 \times 10^{13} C^{2}-3.291 \times 10^{8} C+9922 \\
& E_{\mathrm{D}}=0.02879 D^{4}-4.885 D^{3}+256.0 D^{2}-5859 D+59052
\end{aligned}
$$

これは, カーブフィットで多項式 4 次までを選択し，最小二乗法で計算した結果であるが， $E_{\mathrm{A}}, E_{\mathrm{B}}, E_{\mathrm{D}}$ の式に 関しては 4 次の係数が小さく, 結果としてもつと小さい次数でも有効なカーブフィットが可能であると考えられ る. また， $E_{\mathrm{B}}$ は図 9(b)に示寸ように回帰式であるため多くの変曲点を持っており, 実験データの傾向を適確には 表わしていない. そのため, 制御因子 B の供給空気流量に関しては, この変曲点部分 $(21.5,31.0,37.0 \mathrm{l} / \mathrm{min})$ を新たな制御因子 $\mathrm{B}$ の水準值として, 見かけ上の熱伝達率モデル (式(7)) で計算した結果を図 9(b)に○印で示寸. 図中の $\bigcirc$ 印が $E_{\mathrm{B}}$ の式に近い所にある場合は，そのまま $E_{\mathrm{B}}$ の式を使用するが， $\bigcirc$ 印が $E_{\mathrm{B}}$ の式に近い所にない場合 は, 制御因子 $\mathrm{B}$ の水準数と多項式の次数を増やして, 同様手順で計算を行う必要がある. 本報では, このまま $E_{\mathrm{B}}$ の式を使用することにした，そのため，このことが見かけ上の熱伝達率推定の際の誤差となる.

次に, 各制御因子（強アルカリ水流量, 供給空気流量, ノズルの噴射口断面積, 噴射角度）と最終特性值（見 かけ上の熱伝達率）のそれぞれの関係を，加法性を使用して統合した関係を式(9)に示す.

$$
\begin{aligned}
P_{\text {A B BCD }}= & -7.95 A^{4}+126.6 A^{3}-791.5 A^{2}+4027 A \\
& +0.3414 B^{4}-40.66 B^{3}+1775 B^{2}-33484 B \\
& +4.182 \times 10^{22} C^{4}-3.084 \times 10^{18} C^{3}+6.812 \times 10^{13} C^{2}-3.291 \times 10^{8} C \\
& +0.02879 D^{4}-4.885 D^{3}+256.0 D^{2}-5859 D \\
& +278536
\end{aligned}
$$

熱伝達率を物理的現象からモデル化した先の研究の見かけ上の熱伝達率モデル（式(7)）に比べて, ノズルの噴 射口断面積と噴射角度の 4 つのパラメータを使用して，構成される極めてシンプルな代数式になっている.

最後に, 本節で構築した強アルカリミスト強制冷却システムの最適稼動条件の探索のための見かけ上の熱伝達 率計算モデルを使用して, 最適稼動条件の探索する. 計算モデルは, 稼働条件として強アルカリ水流量と供給空

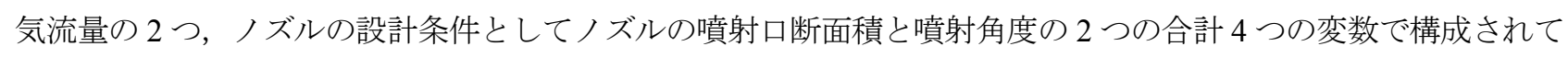
いるが，ここでは最適稼動条件探索のために，ノズルは図 7 を使用寸ることとして, 噴射口断面積 $=1.66 \times 10^{-5} \mathrm{~m}^{2}$, 噴射角度 $=12^{\circ}$ に固定する. また, 現有の装置の変更範囲内で強アルカリ水流量を $0.5 \sim 6 \ell / \mathrm{min}$, 供給空気流量を 20 40 l/min として, 逐次代入法を用いて最終特性值である見かけ上の熱伝達率が最大になる最適条件を探索す る. 表 9 に, 「最適条件探査プログラム」を使用して計算で求めた最適条件とそのときの見かけ上の熱伝達率, ま た, 同条件の実験で測定した見かけ上の熱伝達率をそれぞれ示寸. また, 先の研究の見かけ上の熱伝達率モデル で計算した結果も示した. 本節で構築した強アルカリミスト強制冷却システムの最適稼動条件の探索のための見 かけ上の熱伝達率計算モデルで計算した結果は, 先の研究の見かけ上の熱伝達率モデルで計算した結果と比較す 
Tanabe, Sohichiro Takahashi and Satoshi Takahashi, Transactions of the JSME (in Japanese), Vol.84, No.862 (2018)

Table 9 The forced cooling optimum and heat transfer coefficient using the strong alkaline water mist $($ at $\mathrm{L}=50)$

\begin{tabular}{|c|c|c|c|c|c|c|}
\hline Calculation model & $\begin{array}{l}\text { Water } \\
\text { flow rate } \\
\ell / \mathrm{min}\end{array}$ & $\begin{array}{l}\text { Air flow } \\
\text { rate } \\
\ell / \mathrm{min}\end{array}$ & $\begin{array}{l}\text { Outlet } \\
\text { area } \mathrm{m}^{2}\end{array}$ & $\begin{array}{l}\text { Angle of } \\
\text { injection } \\
\circ\end{array}$ & $\begin{array}{l}\text { Heat transfer } \\
\text { coefficient by the } \\
\text { calculation } \mathrm{W} / \mathrm{m}^{2} \mathrm{~K}\end{array}$ & $\begin{array}{l}\text { Heat transfer } \\
\text { coefficient by the } \\
\text { experiment W/m² } \mathrm{K}\end{array}$ \\
\hline Calculation using eq. (7) & 6 & 40 & $1.66 \times 10^{-5}$ & 12 & 25673 & 26523 \\
\cline { 1 - 4 } $\begin{array}{c}\text { Calculation using eq. (9) } \\
\text { (This paper) }\end{array}$ & 6 & 40 & $1.66 \times 10^{-5}$ & 12 & 24014 & \\
\hline
\end{tabular}

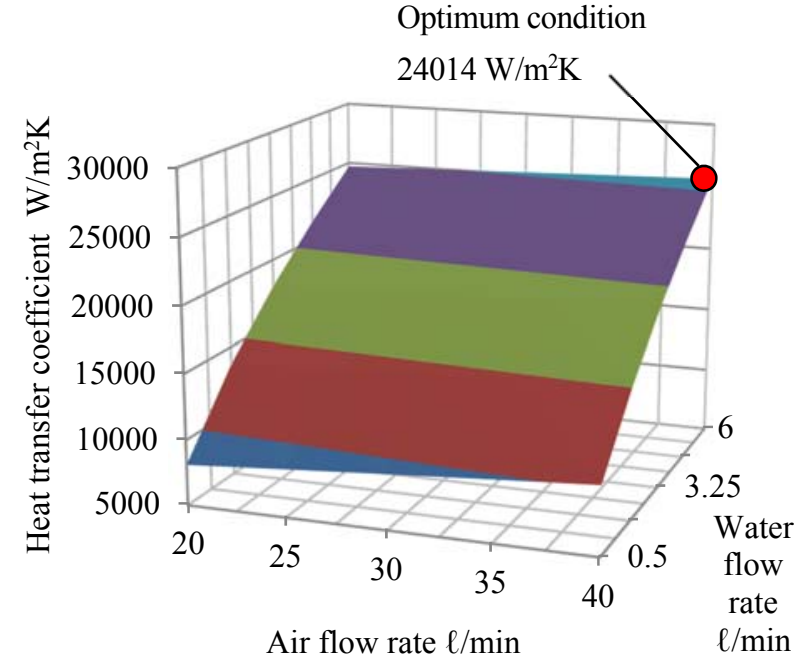

(a) In case of calculation using eq. (7)

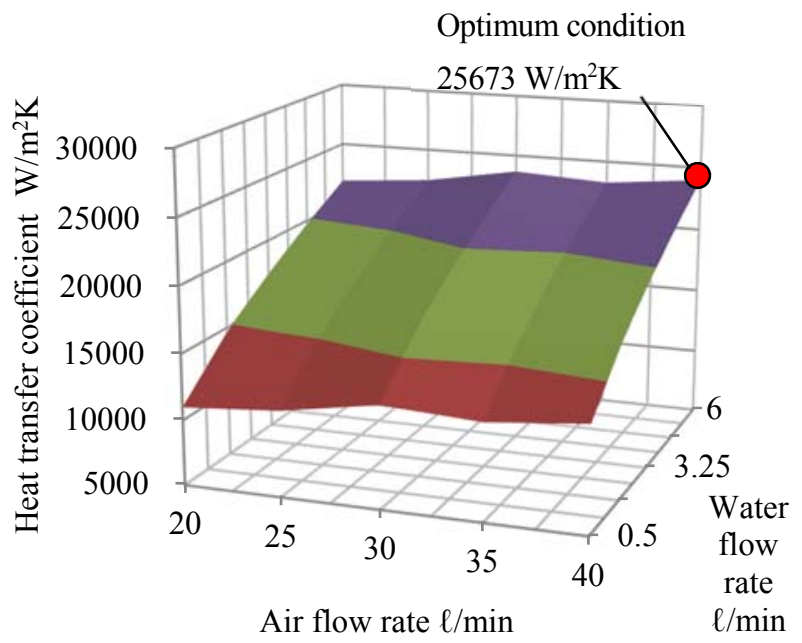

(b) In case of calculation using eq. (9)
$※ \square: 5000 \sim 10000 \quad \mathrm{~W} / \mathrm{m}^{2} \mathrm{~K}$
: $10000 \sim 15000 \mathrm{~W} / \mathrm{m}^{2} \mathrm{~K}$
: $15000 \sim 20000 \mathrm{~W} / \mathrm{m}^{2} \mathrm{~K}$
: $20000 \sim 25000 \mathrm{~W} / \mathrm{m}^{2} \mathrm{~K}$
: $25000 \sim 30000 \mathrm{~W} / \mathrm{m}^{2} \mathrm{~K}$

Fig. 10 Relationship between the heat transfer coefficient and the water flow rate and the air flow rate in the experiment.

ると，誤差は $6.5 \%$ となった．この結果は，本プログラムによって容易に求まる結果として，十分に機能を果た していると考えられる。 また，各計算結果と実験結果も良くあっている.

最後に, 本節で構築した強アルカリミスト強制冷却システムの最適稼動条件の探索のための見かけ上の熱伝達 率計算モデルと先の研究の見かけ上の熱伝達率モデルの両方を用いて, 強アルカリ水流量と供給空気流量を变化 させたときの見かけ上の熱伝達率の計算結果を図 10 に示寸。このとき，噴射口断面積は $1.66 \times 10^{-5} \mathrm{~m}^{2}$, 噴射角度 は $12^{\circ}$ とした．最適条件のときが見かけ上の熱伝達率が最も大きいことがわかる．このように，本手法を使用す ることで, 各制御因子と最終特性值 $P$ の関数関係を明らかにすることが可能であり, それを使用して最適条件を 計算することも可能であり，工業的にも有効に利用可能であった．また，この各制御因子と最終特性值 $P$ の関数 関係は，管理のデータベースとしても有効に利用可能である.

\section{5. 結 言}

実験計画法結果をもとに, 各制御因子と最終特性值 $P$ の関数関係を明らかにするアリゴリズムを構築し, 最適 条件を探索するプログラムを開発し，評価した，その結果，以下の結論を得た。

(1) 各制御因子と最終特性值 $P$ の関数関係を明らかにするアリゴリズムが構築できた. 
(2) このアルゴリズムを使用した計算精度は，制御因子 $\mathrm{A} ， \mathrm{~B} ， \mathrm{C}$ に含まれる誤差 $\Delta A_{\mathrm{S}}, \Delta B_{\mathrm{T}}, \Delta C_{\mathrm{M}}$ がそれぞれ

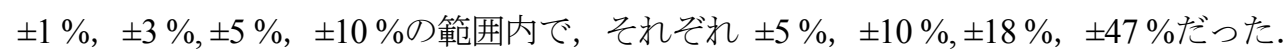

（3）強アルカリ水ミストの強制冷却実験では，その最適条件を容易に探索することができ，本手法の工業的有効 性が評価できた。

\section{文献}

藤川真一郎, 品質工学による 3 次元鍛造変形の有限要素解析パラメータの最適設計, 塑性と加工, Vol.40, No.466 (1999), pp.1061-1065.

井山徹郎, 田辺郁男, 高橋勉, 超硬金型の自動ラッピングシステムにおけるラップ剂の最適化とその評価, 日本 機械学会論文集 C 編, Vol.75, No.749 (2009), pp.210-215.

磯村依和男, 水巻哲, 混合ガスとして算出した湿り空気の粘度, 化学工学, Vol.23, No.7 (1959), pp.467-470.

神蔵一義, 大工原徹, 渡邊泰行, セミドライによる高速深穴加工条件の最適化, 品質工学, Vol.14, No.1 (2006), pp.93-100.

小村昭義, 小橋啓司, 岩重健五, 服部憲一, 渡辺孝, 回転通風機に関寸るパラメータ設計, 品質工学, Vol.20, No.3 (2012), pp.116-122.

水谷淳之介, 浜本智, 向山俊博, 田辺郁男, 山田泰弘, エッチングを用いた微細加工の機能性評価, 品質工学, Vol.10, No.1 (2002), pp.84-90.

森泰彦，山田喜直，杉浦晃治，森義和，中島建夫，消臭不織布マスクの開発，品質工学，Vol.24，No.1 (2016), pp.22-29.

西岡孝夫，伊藤邦夫，小径ドリル穴の高速加工の検討，品質工学，Vol.12, No.3 (2004), pp.85-89.

清水裕浩, 武澤泰則, 天谷浩一, 矢野宏, マシニングセンタの工具マガジンの直行表を用いたソフトウェア評価, 品質工学, Vol.24, No.1 (2016), pp.15-21.

Tanabe, I., Development of Forced cooling using mist of strong alkaline water for restraining thermal deformation on a machine tool, MM Science Journal, December (2014), pp.521-526.

Tanabe, I., Sakamoto, H. and Miyamoto, T., Development of innovative tool using Taguchi-Methods, AASRI Procedia, Vol.9 (2014), pp.107-113.

Tanabe, I., Development of a tool for the easy determination of control factor interaction in the design of experiments and the Taguchi methods, WSEAS Transactions on Electronics, Vol.8 (2017), pp.59-65.

日本機械学会編，伝熱工学資料，改訂第 4 版 (1986), p.122.

日本機械学会編, 伝熱ハンドブック (1993), pp.423-427.

植田辰洋, 気液二相流-流孔と熱伝達-, 株式会社養賢堂 (1981), p.11.

結城宏信，甲斐大介，マハラノビス・タグチ法の $\mathrm{AE}$ 波初動部同定への適用，日本機械学会論文集 C 編, Vol.79, No.797 (2013), pp.145-149.

\section{References}

Fujikawa, S., Optimum parameter design using the Taguchi method for finite-element analysis of 3D forging deformation, Journal of Japan Society for Technology of Plasticity, Vol.40, No.466 (1999), pp.1061-1065 (in Japanese).

Iyama, T., Tanabe, I. and Takahashi, T., Optimization of lapping slurry in automatic lapping system for dies with cemented carbide and its evaluation, Transactions of Japan Society of Mechanical Engineers, Series C, Vol.75, No.749 (2009), pp.210-215 (in Japanese).

Isomura, I. and Mizumaki, T., The viscosity of humid air, Chemical engineering of Japan, Vol.23, No.7 (1959), pp.467-470 (in Japanese).

Kamikura, K., Daikuhara, T. and Watanabe, Y., Optimization of high speed deep-hole drilling conditions with mist coolant, Journal of Quality Engineering Society, Vol.14, No.1 (2006), pp.93-100 (in Japanese).

Komura, A., Kobashi, K., Iwashige, K., Hattori, K. and Watanabe, T., Parameter design for air-cooling of rotating machine, Journal of Quality Engineering Society, Vol.20, No.3 (2012), pp.116-122 (in Japanese).

Mizutani, J., Hamamoto, S., Mukaiyama, T., Tanabe, I. and Yamada, Y., Functional evaluation of a micro-polishing process by a combined method of physical and chemical treatments, Journal of Quality Engineering Society, Vol.10, No.1 (2002), 
pp.84-90 (in Japanese).

Mori, Y., Yamada, Y., Sugiura, K., Mori, Y. and Nakajima, T., Development of the nonwoven fabric mask with a deodorant function, Journal of Quality Engineering Society, Vol.24, No.1 (2016), pp.22-29 (in Japanese).

Nishioka, T. and Ito, K., Study of conditions for microdrilling process with high-speed spindle, Journal of Quality Engineering Society, Vol.12, No.3 (2004), pp.85-89 (in Japanese).

Shimizu, Y., Takezawa, Y., Amaya, K. and Yano, H., Machining center tool magazine software evaluation using an orthogonal array, Journal of Quality Engineering Society, Vol.24, No.1 (2016), pp.15-21 (in Japanese).

Tanabe, I., Development of Forced cooling using mist of strong alkaline water for restraining thermal deformation on a machine tool, MM Science Journal, December (2014), pp.521-526.

Tanabe, I., Sakamoto, H. and Miyamoto, T., Development of innovative tool using Taguchi-methods, AASRI Procedia, Vol.9 (2014), pp.107-113.

Tanabe, I., Development of a tool for the easy determination of control factor interaction in the design of experiments and the Taguchi methods, WSEAS Transactions on Electronics, Vol.8 (2017), pp.59-65.

The Japan Society of Mechanical Engineers ed., JSME data book: heat transfer, 4th edition (1986), p.122, (in Japanese).

The Japan Society of Mechanical Engineers ed., JSME heat transfer handbook (1993), pp.423-427, (in Japanese).

Ueda, T., Gas-liquid two-phase flows, Yokendo Inc. (1981), p.11 (in Japanese).

Yuki, H. and Kai, D., Application of Mahalanobis-Taguchi method to identification of the initial motion part in acoustic emission waveforms, Transactions of Japan Society of Mechanical Engineers, Series C, Vol.79, No.797 (2013), pp.145149 (in Japanese). 